\title{
The Three Models of China's Agricultural Development: Strengths and Weaknesses of the Administrative, Laissez Faire, and Co-op Approaches
}

\author{
Philip C. C. Huang \\ Law School, Renmin University of China \\ History, University of California, Los Angeles \\ huang@history.ucla.edu

\section{中国农业发展三大模式: 行政、放任、与合作 的利与弊}

\section{黄宗智}

\begin{abstract}
This article demonstrates how the "old agriculture" of grain production operates today mainly by an administrative model, while the "new agriculture" of high-value-added products (high-end vegetables, fruits, meat-poultry-fish, and eggs-milk) operates mainly by a laissez faire market model. The former serves to protect low-value agricultural products from violent market price swings and international competition to ensure China's "grain security," but is prone to a commandist approach that can disregard peasant interests and wishes. The latter has stimulated peasant initiatives through market incentives, but suffers from violent price fluctuations and merchant extractions. A third model, "specialty co-ops," has thus far been guided by a mistaken model of trying to imitate U.s. co-ops, which are purely economic entities, to the disregard of Chinese village communities. This article urges the adoption of an "East Asian" model of semi-governmental, integrated co-ops based on peasant communities (villages), extending from there up through the governmental hierarchy of townships, counties, provinces, and the central levels. Such co-ops provide "vertical integration" (processing and marketing) services for small-peasant agricultural products, offer technical assistance, organize the purchase and supply of agricultural inputs, extend credit services, engage in community activities, and see to peasant social-political interests, as was done so successfully in Japan-Korea-Taiwan, most especially during the period when their per capita GDP and relative proportions of industry and agriculture stood at levels roughly comparable to China's today.
\end{abstract}

* My thanks to Kathryn Bernhardt, Gao Yuan, Zhang Jiayan, and a group of Shandong local agriculture cadres for encouragement and helpful suggestions. 


\section{Keywords}

old agriculture, new agriculture, integrated co-ops of Japan-Korea-Taiwan, Marxist ideology, neoliberal ideology

\section{摘要}

本文论证, 中国的“旧农业”一谷物生产——天主要运作于一个 行政模式之下, 而 “新农业”一高值蔬菜、水果、肉一禽一鱼和蛋奶一一则主 要运作于一个放任的市场模式之下。在国际市场竞争和粮食价格相 对低廉的压力下, 前者起到保护中国谷物生产和 “粮食安全” 的作用, 但也 显示倾向过度依赖指令性手段和无视农民意愿的弱点。后者则成功地凭借市 场收益激发了小农的创新性, 但经常受到市场价格波动的冲击以及商业资本 的榨取。作为第三种模式的 “专业合作社”, 则主要试图模仿美国的 纯经济性合作社模式, 无视中国村庄, 不符合中国实际。本文提倡, 中国应该 模仿 “东亚” 模式的半政府性综合农协，扎根于村庄社区、由此往上 延伸到乡-镇、县、省、中央各级政府。它们主要为小农提供 “纵向一体化” 的产品加工和销售服务、技术咨询与服务、信贷服务、组织农资供销、组织 社区活动、并参与国家政治来维护小农利益, 一如日-韩-台历史经验中, 在 其人均GDP以及工农业所占相对比例大致相当于如今中国的那段时期。

\section{关键词}

旧农业、新农业、日-韩-台综合农协、马克思主义、新自由主义

The successive Number One Documents of the Party Central for the past thirteen years (2004 to 2016) have had as their main subject the development of Chinese agriculture. Those documents have spoken in substantial detail about agriculture, but have not distinguished between the old "open field" agriculture (mainly of grains, but also cotton and edible oil) and the new capital and labor dual intensifying small-scale agriculture of higher-value-added products, like (higher-end) vegetables and fruits, meats-poultry-fish, and milk-eggs. The two types of agriculture have in fact operated under very different institutional environments and principles, one mainly by an administrative model and the other a laissez faire market model. A clarification of the differences and similarities, and strengths and weaknesses, of the two models will serve to clarify both.

A third model spoken of in the Number One Documents is specialty co-ops 专业合作社, patterned after U.S. co-ops and intended to be purely economic entities organized around certain specialized products. But the results of the development of those have thus far been modest to dismal, given the present institutional obstacles and the state's favoring of the administrative and laissez faire market models in practice.

This article analyzes the reasons for the successes and failures of each of the three models, and ends with suggestions for a modified approach, based on a combination of the different strengths of the three models: the marketist, to continue to harness peasant initiatives; the administrative, to provide a more appropriate institutional framework and leadership; and community-based integrated co-ops, to see to the vertical integration of agriculture (processing and marketing), and to protect peasant interests. 


\section{The Administered Old Agriculture}

\section{The Old Agriculture and the Administrative Model}

China's old agriculture of grain farming has undergone considerable change in the Reform period, but it has remained still an elaborately state-administered system. Today, it operates under a national plan of developing and maintaining a host of "key grain-producing areas" in which the government sets output targets under a long-term strategic plan calling for those areas to carry the main burden of ensuring “the security of the nation's grain supply”粮食安全. True to its declared intent to “give lots [to] and take little [from agriculture]" 多予少取, the state abolished the agricultural tax formally and completely in 2006, and has also instituted a host of special subsidies for growing grain and purchasing modern inputs like agricultural machinery and improved seeds. In addition, the central government initiated in 2005 sizable special appropriations to reward counties that are major grain producers. In the year 2010, such appropriations 奖励资金 from the Center to nearly a thousand counties for grain growing totaled 21.0 billion yuan, and in 2011, 22.5 billion yuan, or an average of more than 20 million yuan per county ("2011 nian guojia zhichi liangshi," 2011: section 7).

The state, of course, has long operated an elaborate network of organs and agencies for grain collection and marketing, especially through its grain control and collection stations 粮管所 and its supply and marketing "stations" 供销社 (literally "co-ops," but given the current reality that these are state administrative entities, the term "co-ops" would be misleading), such that in the main grain growing areas, the peasant producers' role pretty much ends with the delivery of grain to the state control and collection stations (or to merchant intermediaries or peddlers who will deliver the grain for them for a slight cost). Processing, storage, and marketing are also largely provided by the state, this in sharp contrast to the new agriculture in which peasants generally must see to processing and marketing on their own (more below).

In addition, the government has followed a policy of aggressive intervention to stabilize grain prices, setting minimum floor prices (at which the state will buy the grain) and storing huge amounts of grains (and cotton and also pork), with newly built granaries that have a storage capacity of 100 million tons (or about a sixth of the total annual output of grain, and more than a third the amount of the "circulated" grain), ${ }^{1}$ lest market fluctuations disrupt "grain security" (Liangshi shouchu gongying, 2015: chap. 1, section 1). This contrasts sharply with the higher-valueadded new agriculture, wherein prices of products often fluctuate violently (more below). ${ }^{2}$ The high priority given to grain production is reflected in making grain

1 Consumer households store an estimated combined total of half of all grain produced.

2 In 2014, the approach of setting a floor price was changed to a policy of “targeted prices" 目标价 格制度, with a more flexible policy of the government buying when the price is low and selling when it is high, in order to approximate a "targeted price" 目标价格 for grain (principally wheat, rice, corn) (“Zhongyang yihao wenjian," 2014). 
production the responsibility of provincial governors 省长负责制 (“Zhongyang yihao wenjian," 2014).

From the start, there was also a special emphasis on subsidizing and supporting large-scale grain farms, which were thought to be able to lead in the development of grain production. The 2006 Number One Document spoke explicitly of developing large "dragon-head enterprises" 龙头企业 and model “demonstration areas” 示范区, a theme that has been repeated in all subsequent Number One Documents ("Zhongyang yihao wenjian," 2006, and subsequent years to 2016). Later, most especially in the 2013 document, the state added to dragon-head enterprises other larger-scale entities for special support, spelled out as "big specialty farms” 专业大户, “[big] family farms” (generally over $100 \mathrm{mu}$ ) 家庭农场, “specialty co-ops” 专业合作社, and “other new-style production and management entities” 其他生产经营主体 (“Zhongyang yihao wenjian,” 2013). But those in reality account for just a small fraction of all grain farming and are intended as "models" for the state-set direction of development (more below).

\section{The Record}

Together the new measures have turned grain growing from what had become a non-lucrative pursuit in the 1990s and early 2000s, given the burdens of taxes and fees and the relatively low prices of grain, which caused many peasants to leave their responsibility land unplanted, into something with at least significant net returns (typically now of 500 to 1,000 yuan per mu in the main grain-producing areas).

Given the household responsibility land system instituted since the start of the Reform period, technological advances, and the growing government-administered encouragement of grain production in recent years, yields per $m u$ have more than doubled in the period 1980-2014, at a rate of increase of about 2 percent a year (see Table 1$),{ }^{3}$ most certainly a record of sustained increase (even though it pales by comparison with the six-fold increase in output value in the new agriculture, as will be seen below).

Those results attest to the accomplishments of what might be dubbed "the administrative approach," or administered development of the grain economy, and also show striking continuities with the past planned era: under the planned economy between 1952 and 1979, agricultural output grew at the rate of 2.3 percent a year (Perkins and Yusuf, 1984: esp. chap. 2), roughly the same rate. The difference in the Reform era is that grain production is no longer simply a matter of planned commands and quotas, but more of incentivizing peasants to engage in such production according to state-set targets. It might even be considered illustrative of "guidance planning” 指导性计划 / 规划 as opposed to the "command planning” 指令性计划 of the pre-Reform era (Huang, 2013).

3 The state in its announcements has made much of the record of successive years of continued increases in grain output, but those have in fact amounted to a total of only about a 7 percent increase in the four years between 2010 and 2014, or less than 2 percent a year. 
Table 1. Yields of the Main "Old Agriculture" Crops, 1980-2010 (catties per mu)

\begin{tabular}{llll}
\hline Year & Grains & Cotton & Rapeseed \\
\hline 1980 & {$[401]^{\mathrm{a}}$} & 81 & 123 \\
1985 & {$[546]^{\mathrm{a}}$} & 118 & 183 \\
1990 & $617^{\mathrm{b}}$ & 118 & 185 \\
1995 & 683 & 129 & 207 \\
2000 & 697 & 160 & 223 \\
2005 & 766 & 166 & 263 \\
2010 & 810 & 180 & 260 \\
2014 & 864 & 215 & 286 \\
\hline
\end{tabular}

${ }^{\mathrm{a} B r a c k e t e d ~[~] ~ n u m b e r s ~ a r e ~ f o r ~ r i c e ~ a n d ~ w h e a t ~ o n l y . ~}$

b1991 data.

Note: Two different terms/categories are frequently applied to grain production. One, the less inclusive and more specific, is "grains" or “food grains" 谷物, mainly rice, wheat, and corn. The other, the more inclusive term, is “staple food-crops” 粮食, which includes not only grains but also near-grains or grain substitutes, most especially potatoes and beans. Different figures are used for the two categories, the latter being substantially larger than the former. The figures used in this article are of the narrower sense of (food-) grains, which includes grains for human consumption as well as animal feed. Sources: Zhongguo tongji nianjian, 1983; 1984; 1987; 2011: table 13-16; 2015: table 12-11.

There has come in the past two decades quite an increase in the use of modern inputs - powered not only by state subsidies and investments but even more by the rising opportunity cost of agricultural labor. Once off-farm employment incomes reached levels higher than the cost of purchasing machine plowing-plantingharvesting services (which have mushroomed across the country, especially in the wealthier areas), peasants have purchased those services, leading thereby to unmistakable "modernization" (or "capitalization," in the sense of increased modern/ capital inputs per unit land and labor) in this "old" agriculture. The use of tractors at least doubled in the decade 1996 to 2006, according to the very comprehensive first and second decennial national surveys of agriculture. If we were to trust in the data compiled by the State Statistical Bureau on the basis of its sample of 60,000 farms in 1,553 counties (which likely favor trend-setting farms more than typical farms), machine use rose five- to six-fold, and the application of weed killers two- to threefold, between 1996 and 2010 (Huang and Gao, 2013: figures 1 and 2, p. 31). Peasant households, by purchasing such services, are in effect paying for those modern inputs with their earnings from off-farm employment, the more so with peasant households in which the younger and/or principal labor units have taken on offfarm employment without leaving their home villages 离土不离乡, as opposed to those who have left home for more distant urban employment 离土又离乡.

The big issue in 2015, as pointed out in that year's Number One Document, was that Chinese grain prices had risen above international prices ("Zhongyang yihao wenjian," 2015). That made for an additional reason for the approach taken: the state must play this crucially important role of seeing to "grain security" as well as 
competitiveness on the global market. Indeed, given rising Chinese agricultural labor costs and the relatively low price of grain, this administrative model might well be the only way for grain production to remain viable in China (the problems with the approach will be discussed below).

Some scholars see this present-day grain economy as somehow already completely, or mainly, or irrevocably capitalist, because of the state's evident favoring of the dragon heads and larger-scale farms, and because of the high degree of commercialization of the agricultural economy. They point to the 2013 official statistic of a cumulative total of 340 million $m u$ of "transferred 流转 land" as evidence of the overwhelming tide of capitalism in Chinese agriculture (Zhang, Oya, and Ye, 2015: 308). Yet we know from field studies that most village land that has been "transferred" has not gone to large capitalist farms but rather to relatives and neighbors by those who have left to work off-farm (but most of whom intend to return to or keep open the possibility of returning to the village in the future). We also know, from the exhaustive decennial surveys of Chinese agriculture in 1996 and 2006, that despite the state's long-standing favoring of dragon-head enterprises, in 2006 still just 3 percent of the total agricultural labor force were working as full-time hired workers (Huang, Gao, and Peng, 2012). Even if we allow for a massive increase in recent years of transfers of land to labor-hiring capitalist farms, big farms, and “[big] family farms" (of more than $100 \mathrm{mu}$ ) under the state's aggressive promotion of them, total land transferred to big farms most assuredly still amounts to no more than a fraction of the 340 million $m u$ total of all transferred land, which is in turn just about a sixth of total cultivated land. In other words, the majority of the agricultural labor force working China's two billion $\mathrm{mu}$ of cultivated land, without doubt, are still working their own responsibility land in smalland medium-scale farms. The 2016 third decennial agricultural survey, once made available, should give us more conclusive and precise figures.

As suggested above, a number of strategic considerations lie behind the highly interventionist and administrative approach to the grain economy. The state remains very much preoccupied with what it calls "grain security," insistent on maintaining Chinese autonomy in the supply of grain for the Chinese people. The policy has deep roots that go back at least to the mid-Qing period, the eighteenth century, when population began to outrun grain output, causing periodic massive hunger and famine and a permanent "floating population" dislocated from their home locales. It also goes back to the revolutionary base areas' struggle for survival in a hostile environment - the biggest concern being the threat of hunger and famine as a result of enemy blockades. And, more immediately, it goes back to the memory of "the three difficult years" of 1959-1961, when China suffered massive hunger and deaths.

We should note also that the government has not been rigid in its preoccupation with "grain security." Perhaps the best example is what it has done with soybeans (also a part of the old agriculture), both a grain substitute and a major source of proteins and, today, an increasingly important source of animal feed. China now imports four times more soybeans than it produces itself. It imports 
huge quantities of genetically altered soybeans (especially from the United States, Brazil, and Argentina), while prohibiting domestic production of such. The imported soybeans go mainly toward animal feed and soybean oil, this because the international price is considerably lower than the domestic price and also because the genetically altered soybean is actually superior as a source of animal feed and of oil. China's long-term strategy appears to be to maintain the domestic production of the natural soybean, preparing for a future when it might break through to a significant international market of high-value health foods. The basic economic calculation seems to be that the land freed up by imports can be better used for higher-value products than soybeans, while taking advantage of low global prices to obtain what it does need-most especially the increased animal feed needs from China's burgeoning beef and other animal husbandry. If China itself were to produce all the soybeans it currently consumes, it would have to place another 400 million $\mathrm{mu}$ (a fifth of its total cultivated acreage) under soybeans - something that is simply unthinkable. We might even say that China is at present trading land under low-return soybeans for land under higher-value products and paying for soybean imports with exports of higher-value agricultural products-something that makes good economic sense (for detailed documentation and analysis, see Huang Zongzhi and Gao Yuan, 2014: 179ff). It is certainly arguably a practical and flexible strategy.

While Marxist scholars both outside and inside China are certainly right to criticize the Chinese government's current proclivity for capitalist agriculture, we need to see also that capitalist enterprise is most certainly not the main organizational form of the present grain economy. That economy is, in fact, above all still an administered economy of small-peasant farms, showing the legacy of the old planned economy even more than the marketized and capitalist features of reform. It is in no way a completely "marketized" economy, given the immense role still played by state planning and administration. It is in fact best understood as a kind of administered small farming, this in addition to the fact that the majority of grain production still comes from small family farms. To consider it simply "capitalist" agriculture, or agriculture dominated by capital bent on accumulation, would be mistaken. Of course, to understand such agriculture in terms simply of neoliberal theory would be similarly mistaken: it either overestimates the degree of success of capitalist agriculture or underestimates the positive role the state has played.

\section{The Problem}

In looking to the future, the state has pinned its hopes on large-scale grain farms. Earlier it had favored dragon-head enterprises with subsidies, and more recently, other large-scale farms including large "family farms" and also capitalist enterprises that are posing as co-ops to obtain state subsidies. In the long run, we might say, the policy-makers hope to rely on large corporations and corporate entities to sustain China's grain economy. Part of the consideration, nodoubt, is that to overcomeChina's weakness in grain production compared to much more highly land-intensive and mechanized foreign producers, China too must resort similarly to economies of scale. 
The problem with such considerations is not only a misplaced trust in economies of scale, but also reinforcement of the old planning mentality, albeit with a significant modification from commandist planning to guidance planning, from implementation by orders and control to incentivizing peasants to comply with the state's wishes. What the policy-makers have shown is excessive trust in large capitalist entities and a fundamental distrust of small peasants. That attitude is evident in their failure to take into consideration the truly major dynamic in agricultural development of the past thirty-plus years-namely, of small-peasant producers turning to produce more and more high-value-added products of the new agriculture (more below).

The excessively administrative attitude becomes graphic when state predilections and controls have led to utter disregard for peasant choices and interests, and to coercion to force peasants to do the state's bidding. Double-cropping of rice (early rice + late rice + winter wheat) is especially illustrative. Such cropping practices had long been shown to be only good from the point of view of increasing total (grain) yield per unit cultivated land but not in maximizing returns per unit (liquid) input (of labor and fertilizer, insecticides, improved seeds, and the like) for the peasants. In the 1960s, double-cropping of rice had been pushed aggressively, with the slogan of "eliminate single-cropped rice!" But peasants were most reluctant, because double-cropped rice requires nearly double the labor and liquid capital inputs, but produces much less than double the returns. By the 1980s, with the loosening of state control, it had largely been given up (Huang, 1990: 225-28, 240-41). But in recent years, under the drive for "grain security," it has been pushed aggressively once more, even though the reality is that in the present institutional environment, returns to the peasant farmer per unit area of double-cropped rice are actually less than those from a single cropping.

The example of Pingwan (pseudonym) county in Hunan graphically illustrates the problem. What the double-cropping policy led to was massive resistance from below, in the form of deception and pretense. In 2013, local officials in Pingwan managed to represent placing only about 40 percent of the cultivated area under double-cropped rice as more than 90 percent, this by using loopholes in the state inspection system. Such inspections tend to focus on areas close to major thoroughfares that inspectors would pass through in their cars. The locals therefore fabricated a “core model zone” 核心示范圈, complete with model seed-growing farms that created the illusion of seed-growing in sufficient quantity for pervasive planting of double-cropped rice, as well as dressed up models of double-cropped farms and falsified statistics of double-cropping of rice. The deception was exposed by an investigative reporter, and confirmed by the academic field researcher Gong Weigang (though the latter has been constrained to keep the original report as well as the county name confidential, lest local interests be directly impacted) (Huang Zongzhi, Gong Weigang, and Gao Yuan 2014: 145-50).

Where double-cropping of rice has actually taken hold, it has become a matter of larger farms profiting not from their superior productivity but rather from artificially expanded scales of production and state subsidies. The program went 
through three phases in this locality: first relying mainly on a big local dragon-head enterprise that contracted to do all the work, but that approach failed because the expenses of land rent and hired labor were simply too high, and also because peasants found that the work done by hired workers of the firm, for which the firm charged 350 yuan per $m u$, simply did not meet the standards they expected. Then the project turned to village cadres, who found that peasants were reluctant to participate, because they knew that double-cropping of rice, after all the costs incurred, actually netted less than one single-cropping of rice. So the cadres, under pressure from above, took on the burden themselves of the responsibility for growing double-cropped rice. But that was clearly not sustainable. In the end, beginning in 2012, the local model that emerged was to rely on "big households" through the instigation of local authorities (Huang Zongzhi, Gong Weigang, and Gao Yuan 2014: 145-50).

That was in fact a system in which only the officials and the big households benefitted, but not in terms of actual net incomes per unit land. The officials benefitted from the state's reward of more than 10 million yuan to the county government and their own career advancement. As for the big households, they are able to net only about 500 yuan per mu from double-cropping rice, and then only with the state's subsidy of 150 yuan per mu, compared to the 1,000-odd yuan a small-peasant farm could net from just one crop of single-cropped rice. But big households were willing to join in because, by taking on many $m u$ with the help and support of the local authorities, they could actually earn more total income from all land cultivated than their fellow villagers, the smaller peasant farmers: by "transferring in" 流转 100 or $200 \mathrm{mu}$, with a net earning of 500 yuan per $\mathrm{mu}$, they could earn by virtue of sheer size a total of 50,000 yuan or 100,000 yuan a year, far more than a small farm of $10 \mathrm{mu}$ netting 1,000 yuan per $\mathrm{mu}$, which added up to a total income of only 10,000 yuan. Those big households can therefore still tower far above their neighbors in total farm earnings. Of course, they could also ingratiate themselves with the local authorities (Huang Zongzhi, Gong Weigang, and Gao Yuan 2014: 145-50).

Such a mechanism, of course, satisfies only the local officials and big households, and the state's grand strategy for "grain security" and large-scale production, but little else. Certainly not the small peasants who know only too well that a single cropping of rice can bring higher returns than double-cropping. The entire scheme is in fact simply anti-economic. It is sustained not by economic logic, but by state imposition and administration (Huang Zongzhi, Gong Weigang, and Gao Yuan 2014: 145-50).

Double-cropped rice is an example of the weaknesses and cracks of an overly administrative and control-based approach to agricultural development, to the disregard of fundamental economic principles (net returns given costs/benefits and input/output logics at the farm level). It dramatizes the problems that can occur with excessive control and planning, with the administering of "development," without regard to peasant wishes and the realities on the ground. It tells about the failures of a system that disregards peasant interests and deprives peasants of their own choices. 
The most worrisome thing is that under such irrational state dictates, this administrative + big-farms approach is the only model that might achieve the state's grand strategy. The big households make things easier for the state to control, because there are fewer of them and also they are more dependent on the state's (local governments') good wishes. (Compare three thousand farms cultivating four mu each with $60 \mathrm{big}$ farms cultivating $200 \mathrm{mu}$ each.) As for the officials, they make things look good to their superiors, seeming to make the state's strategy work and confirm its correctness. The danger of course is that such a mode of operation would become self-proliferating and self-perpetuating, at the cost of drastic inefficiencies in the uses of labor and other inputs and genuine agricultural development. It also works against the interests of small producers by compelling them to undertake anti-economic double-cropping of rice. It is, in short, a system that represents the worst of uneconomical "blind commandism," sustainable only at the great cost of state subsidies and administrative control.

A host of solidly grounded empirical studies by fine young scholars have made crystal clear that the mainstay of the present-day grain economy is in fact not the state-favored big farms but rather middle-scale farms of 20 to $50 \mathrm{mu}$ that rely almost entirely on family labor. Those farms have enlarged the scale of their operations by transferring in, at relatively low cost (often by a merely symbolic or gift-like payment), land that would otherwise be left fallow by relatives and neighbors who have gone away for off-farm work. They have enjoyed the advantage of not having to hire in labor in the manner of the big farms, much less hiring supervisors for the laborers. As off-farm wages have risen, the strongest laborers of the household have been able to work off-farm by purchasing machine plowingplanting-harvesting services from the entities that have arisen to meet the need, and manage the farming with their own lower-cost, middle-aged, or female and elderly labor. That is how such farms have been able to net 1,000 yuan or more from a single cropping of rice, as opposed to the mere 500 yuan odd that the big farms have netted from double-cropping (Zhang, Cao, and Yang, 2016; Gao, 2014; Lin Huihuang, 2012; Yang Hua, 2012).

As these scholars have made clear, such "middle peasant" farms, including those that combine off-farm work with farming (e.g., the younger generation or the men hiring out off-farm, what I have called "part worker part cultivator" 半工半耕 peasants-Huang Zongzhi, 2006) to reach "middle incomes" (of more than about 20,000 yuan), have accounted for a larger and larger proportion of all farms. (See especially Zhang Jianlei, n.d.: chap. 7.) They have also been the ones who are most centrally concerned about village affairs and services- the mainstay not just of agriculture but also of (what is left of) the village community. The Central's Number One Documents, however, have not recognized at all the role they have played, but have continued to prefer large farms, on the basis of an absolutized belief in the "law" of "economies of scale" — an article of faith in both neoliberal and Marxist theory.

On balance, we might say that, given the special circumstances and needs of Chinese grain production-the imperative to feed a large population, the 
necessity for "grain security," the reality of small-farm production of grain, and the pressures of global competition from the lower prices of grain from land-abundant countries - a definite degree of state administrative intervention in market dynamics and administrative support of grain production is necessary and unavoidable. What is needed is to hold in check ideologically driven excesses, especially over-emphasizing large farms to the neglect of or even at the expense of small ones, to the detriment of small-peasant interests.

\section{The Free Market New Agriculture}

\section{The New Agriculture}

The "new agriculture" (my term, referring mainly to production of higher-valueadded agricultural products, especially [higher-end] vegetables, fruits, meatpoultry-fish, and milk and eggs) is very different from the old grain economy. We need to note first the relative scales of the new and old agricultures: as shown in Table 2, in 2010, vegetables + fruits + meats-fish farms accounted for 66.0 percent of total (“big agriculture” 大农业 [农、林、牧、渔]) output value, more than four times that of the old agriculture, which accounted for only 15.9 percent, even though it used 55.9 percent of the sown acreage.

This new agriculture is generally smaller scale, in terms of land usage, than the old-style "open field agriculture." It includes especially what is termed "infrastructure agriculture” 设施农业, such as hothouses and plastic-tented vegetable growing that generally come in one, three, or five $m u$ sizes, characterized as "small," "medium," and "big." A peasant household can typically manage only one such tent. It includes also fruit orchards, which are typically of roughly the same scale. The same goes for poultry-raising structures and fish ponds. Operations combining animal-feed-crops growing and animal husbandry 种养结合, though larger than "infrastructure agriculture," are typically also rather small scale, just five to $15 \mathrm{mu}$ for a farm raising corn for feed and a few dozen pigs, or cattle, or milk cows.

Table 2. Acreage and Output Value of Major Agricultural Products, as Percentages of Total Sown Acreage and Output Value, 1990-2010

\begin{tabular}{|c|c|c|c|c|c|c|c|c|}
\hline Year & $\begin{array}{l}\text { Vegetables } \\
\text { sown } \\
\text { acreage } \\
(\%)\end{array}$ & $\begin{array}{l}\text { Vegetables } \\
\text { output } \\
\text { value }(\%)\end{array}$ & $\begin{array}{l}\text { Fruits } \\
\text { sown } \\
\text { acreage } \\
(\%)\end{array}$ & $\begin{array}{l}\text { Fruits } \\
\text { output } \\
\text { value } \\
(\%)\end{array}$ & $\begin{array}{l}\text { Grains } \\
\text { sown } \\
\text { acreage } \\
(\%)\end{array}$ & $\begin{array}{l}\text { Grains } \\
\text { output } \\
\text { value } \\
(\%)\end{array}$ & $\begin{array}{l}\text { Animal } \\
\text { husbandry } \\
\text { output } \\
\text { value }(\%)\end{array}$ & $\begin{array}{l}\text { Fishery } \\
\text { output } \\
\text { value } \\
(\%)\end{array}$ \\
\hline 1990 & 4.3 & - & 3.5 & - & - & $31.4^{*}$ & 15.8 & 5.4 \\
\hline 2000 & 9.7 & 14.4 & 5.7 & 4.2 & 54.6 & 17.4 & 18.6 & 10.9 \\
\hline 2010 & 11.8 & 18.8 & 7.1 & 7.9 & 55.9 & 15.9 & 30.0 & 9.3 \\
\hline
\end{tabular}

* Total of "staple food crops" 粮食 (which include potatoes and soybeans). There are no data for "grains" 谷物 alone for that year.

Source: Zhongguo nongcun tongji nianjian, 2011: table 6-14; 2002: table 6-14. 
All such farms are generally both labor and capital "dual intensifying” (in terms of inputs per unit land) by comparison with the old "open field" agriculture (Huang, 2016; cf. Huang Zongzhi, 2010, 2014a).

We do not have good aggregate labor and (fixed and liquid) capital (as opposed to land) input data for the new versus the old agriculture. But the aggregate output value can be used as a very rough indicator of the difference-a ratio of $4: 1$. In vegetable farming, for example, one $m u$ of infrastructure vegetables requires typically that kind of ratio of inputs per $m u$ when compared to open-air vegetable farming. What this means is that the old agriculture remains the most important only in terms of land use (just over half of the sown acreage), but not in terms of labor and capital inputs, most especially not in terms of output value. In other words, we need to stop equating Chinese agriculture with mainly grain agriculture, as so many people continue to do by force of habit.

As for the source of the "capital" investments in inputs, given the small-peasant household's lack of access to credit (more below), they have come mainly from peasants' wage incomes, most especially those of peasants who "leave the soil but not the village." My colleagues and I have estimated that peasant wage incomes totaled about 5,000 billion yuan in 2010. Such income, most especially the close to 2,000 billion yuan income of the leave the soil but not the village peasants, is the source of much of the fixed and liquid "capital" small peasants have invested in agriculture in recent years. As peasants still living with their families in the villages (to be distinguished from those who have migrated to distant places to work), they typically contribute a good deal of their earnings to the family farm. We have estimated that peasant investments in agriculture in 2010, in fixed and liquid capital, amounted to a total of 1,693 billion yuan, nearly two times the total investment by the state of 858 billion yuan in "infrastructure, agricultural technology and research, subsidies and grants to support rural production, and agricultural services." In other words, small-peasant households have been the main engine driving what I have termed the "hidden agricultural revolution," pushing the aggregate output value of the new agriculture up six-fold just in the period 1980 to 2010, and beyond (Huang Zongzhi and Gao Yuan, 2013). The deeper roots of that agricultural revolution will be discussed later in this article.

\section{The Laissez Faire Market Model of the New Agriculture}

There is a very great difference between the new agriculture and the old in terms of the institutional environment under which the farms operate. On the whole, the new agriculture is not under state administration or management to nearly the same extent. There are not the kinds of direct state subsidies given to growers just for farming grain, nor subsidies given for purchasing big tractors (the new agriculture, we have seen, is generally small-scale and does not use farm machinery to nearly the same degree). Nor are there state guaranteed minimum purchase prices or the large-scale state storage of grain for the purpose of "grain security" and the stabilization of grain prices. And there are not the extensive state networks of grain 
collection stations, processing stations, and selling stores. The grain grower's role in grain production, especially in the "main grain growing areas," largely stops with the delivery of the grain to the state-managed stations, with the state doing the rest. The new agriculture, by contrast, is largely a laissez faire market economy. The state has largely trusted in market mechanisms and dynamics for the new agriculture.

The state's active intervention in the new agriculture has been limited mainly to building some large wholesale markets for the purpose of facilitating 带动 market development. However, since such wholesale markets are generally built by a multitude of different state organs, each with its own budgetary concerns and interests, and all under the pressures of the high cost of development land, they therefore almost of necessity must operate on a for-profit basis. They are generally crude structures, mainly just a building, or a tent, or even just open-air spaces where producers, middlemen, and merchants can gather to sell and buy, with little in the way of storage facilities or processing services (Zeng Yinchu, 2007), a far cry from the multiple support structures in the old agriculture.

There have also been aggressive efforts by some local governments to develop localities into centers for specific specialty products and to develop the agglomeration of production, processing, and marketing clusters around certain kinds of agricultural products. Some areas have proven to be highly successful in drawing on the economic benefits of agglomeration (Krugman, 2008), not only of large numbers of small producers, but also of associated processing and marketing. Two notable examples are Shouguang (in Shandong), ranked number 1 in the nation as a center for vegetable production and marketing/trade (Huang Zongzhi, 2014a: 209-10), and Yongnian in Hebei, number 1 in the province for vegetables (Huang Zongzhi, 2015: 29). Within those localities, governments have also initiated or helped develop select villages that have distinguished themselves for the production of certain brands of products 一村一品.

Outside of those, administered state intervention has been limited largely to supporting the large-scale dragon heads and big farms favored by the state, once again under the "models" approach. Large-scale specialty products farms have been favored by state (local governments and the Ministry of Agriculture's) support and subsidies, for inputs, for technical development of name brands, for obtaining credit, and so on. A good example is western Shandong's Xin Xian 莘县 for specialty “small meat chickens" 小 肉 鸡, studied in detail by Yuan Zhonghua (n.d.).

But the great majority of small producers of the new agriculture, even in these locales of agglomeration, have been largely ignored, left to their own means for dealing with large-scale inputs firms (for manufactured specialty feed, seedlings, and technical inputs) and processing firms. Most especially, they have had to arrange for their own marketing. That means relying on a system of layers upon layers of middlemen merchants 中间商 big and small, in which their products must first go through small local buyers and peddlers to large local wholesale merchants, then to wholesale merchants where the products are sold, further to middlemen there before finally reaching consumers. While the old agriculture 
remains very much a part of an administered economy, the new agriculture is much more a "free market" laissez faire one.

\section{The Record}

As noted above, the new agriculture is much more dynamic than the old, shown by its six-fold rise in output value (in comparable prices) during the thirty years between 1980 and 2010, compared with the mere doubling in yields per mu by weight of the old agriculture in that same period. In terms of annual growth rate, while grain output increased (by weight) about 2 percent a year, the output value of the new agriculture increased by about 6 percent a year. In one, it meant a doubling in 36 years; in the other, a doubling every 12 years (Huang, 2016: table 2). That is how the new agriculture has come to make up the bulk of the output value of Chinese "big agriculture," more than four times that of the old agriculture, as shown in Table 2. Along the way, the structure of the Chinese people's food consumption has changed fundamentally-in schematized terms, from a grain: vegetables: meat ratio of $8: 1: 1$ to $4: 3$ : 3 . Changes in food consumption and in agricultural production have been both the cause and the effect of one another.

The dynamics for the development of the new agriculture have come, as I (with Yusheng Peng) have shown, from the confluence of three long-term historic trends: declining birth rates since 1980 and the declining numbers of new people entering the workforce starting around the turn of the century; massive out-migration for off-farm employment; and changes in the consumption patterns of the Chinese people along with rising incomes (Huang Zongzhi and Peng Yusheng, 2007). Together those have resulted in (1) the increase of cultivated area per unit agricultural labor (from $5.9 \mathrm{mu}$ in $1990 \mathrm{up}$ to $10 \mathrm{mu}$ in 2010), and (2) increased peasant household incomes (from the combining of agriculture with off-farm employment). The third factor, and the major driving force, we have seen, has been the revolution in the Chinese people's food consumption habits, something that has come with rising incomes, from the non-farm sectors of the economy, from peasant earnings from off-farm employment, and from the new agriculture itself. Today, Chinese food consumption has come to resemble much more the 4: 3: 3 pattern of grain to meats to vegetables typical of the advanced Japan-Korea-Taiwan economies and the Chinese urban upper middle class, than the traditional 8: 1: 1 ratio (Huang Zongzhi and Peng Yusheng, 2007; cf. Huang, 2016).

From the above record alone, we might say that the new agriculture, with its laissez faire market approach, has been a stunning success, certainly dwarfing the record of the old agriculture. And it has been powered mainly by peasant initiative in response to marketization, switching from lower-return agriculture to more and more higher-value agricultural products, thereby reshaping dramatically the fundamental structure of Chinese agriculture. And, perhaps most surprisingly, peasants in the new agriculture have provided not only the added labor input required for the new agriculture, but also the capital investments, mostly through their offfarm earnings, to drive its stunning development. 
Despite the much greater success and dynamism of the new agriculture, the state has not supported it to anywhere near the extent of its support for the old grain agriculture. It has played a relatively minor role beyond the strategic decision for marketizing and for a "laissez faire market model," promoting agglomeration in select areas, and supporting large entities.

The state has in fact been slow to recognize or acknowledge the reality of the new revolution propelled by the new agriculture. An examination of the successive Number One Documents of the Party Central beginning in 2004 shows little emphasis on the new agriculture in the first few years of the documents, accustomed as state planners are to thinking and speaking of agriculture mainly as grain production. All the Number One Documents have opened with grain production as the primary concern, and have given the bulk of their attention to that old agriculture, detailing the elaborate subsidies, storage, and price-control mechanisms. There was no real mention of the new agriculture in the first two Number One Documents in 2004 and 2005. In the next year, passing attention was given to animal husbandry, but there was no mention at all of new-style vegetable and fruit growing. Not until the 2008 document was there clear mention of both of the major components of the new agriculture: animal husbandry and what is now termed "horticulture" 园艺 (i.e., of “non-staple production, especially of vegetables and fruits," the new term for high-value-added non-staple agricultural production). But there was still no explicit acknowledgment of the new agriculture's great role in the dramatic expansion of the aggregate output value of Chinese agriculture, now almost 30 years after it had become the main propellant of China's hidden agricultural revolution, in 1980-2010 and beyond ("Zhongyang yihao wenjian," 2004, 2005, 2006, 2008).

Some planners, clearly, even now continue to think of the old agriculture as the main agriculture, accustomed as they are to the very long-standing nature and structure of Chinese agriculture. One very high ranking official in agricultural policy making, for example, has recently (in 2016) spoken of the 200 million peasants (the total number of peasants employed in agriculture today) as being engaged in grain production, when the fact is that grain is farmed by less than half of the peasants today, and its output value amounts to less than a quarter of that of the new agriculture.

The lesser importance (and state control) of the new agriculture in the eyes of the administrative hierarchy is shown clearly by the fact that while grain production has been designated the responsibility of provincial governors 省长负责制, just below the level of the Party Central, diversified food production (with nongrain production captured by the newly vogue term "basket of non-staple food" 菜 篮子) has been designated the responsibility merely of city mayors 市长负责制. Not until the 2012 document does vegetable production (and the new term "basket of non-staple food") appear with greater prominence, now elevated to the second paragraph of the document ("Zhongyang yihao wenjian," 2012: 1.2).

We researchers, however, need to see both the old and new agriculture, along with their differences and commonalities. Only then can we make clear that the 
state has exhibited very different attitudes toward them. Toward the old, we have seen, it has employed a predominantly management-by-state-administration approach. Toward the new agriculture, by contrast, the logic of laissez faire marketism has predominated, with the state assuming that markets should be allowed to operate pretty much on their own. In the former, the legacy of the old socialist planned economy is readily evident; in the latter, the predominant influence of neoliberal marketist economic thinking is readily apparent.

\section{The Problem}

For the new agriculture left by the state under laissez faire marketism, the key problem is well known. The pattern has been seen repeatedly almost everywhere, and over and over again: a new product that brings high returns emerges in a locality; many peasants quickly jump on the bandwagon; the market gets saturated and then glutted with unsold products; prices drop sharply, causing big losses to many peasants, until some new and better balance is arrived at between demand and supply. For peasants, it is a precarious mode of operation that has allowed a few to become rich, but also caused insecurity and impoverishment of many.

This is a pattern documented for numerous areas for many crops. To give just one striking example as an illustration: in Shandong's Jinxiang county 金乡县, the largest garlic market in the nation, in 2010 the price of garlic had reached an all-time high of 6 yuan per cattie, but then dropped to just 1 yuan by June 2011. Hundreds of tricycles and trucks and thousands of garlic peddlers lined up for three to five days and could not sell their garlic, making national news. It was learned later that big wholesale merchants had taken advantage of market forces and ganged up to agree not to purchase the new garlic, to deliberately force the price lower, driving it down to 1.25 yuan before they bought. They then turned around and sold the cheap garlic at 4 yuan per cattie, deriving huge profits. Here market volatility had been deliberately aggravated by large-scale wholesale merchant capital to enlarge its profit margin ("Dasuan," 2011; cf. Huang Zongzhi, 2012: 88).

Parallel price movements occurred at the same time in ginger, though without the accompanying big wholesale merchant conspiracy, this because ginger can be stored in cellars 地害 for longer periods and is hence better able to withstand market fluctuations (Huang Zongzhi, 2012: 88-89). The problem of periodic overproduction beyond market demand is of course common to just about all market economies. It becomes more severe with perishable goods that need to be sold and consumed fresh, goods that cannot be stored for any lengthy period to withstand shorter-term market fluctuations.

\section{The State's Actions}

The state's response to the problem of price volatility of the "big market" thus far has been mainly laissez faire, nothing like what it has done in the grain economy. When the state interferes, it has not been like in the old economy's guaranteed 
lowest purchase price and massive storage to control the market, but rather merely to strive for technical improvements. To give just one example, of carrots production in Hualong township 华龙镇 in western Shouguang county: what the local township government did was to put much effort and investment behind "deep processing” 深加工, in this case in the freezing and preservation of carrots, producing canned sliced carrots (that actually had a market value five times that of the raw carrot), thereby giving a cushion (of 50,000 tons of carrots) to absorb some of the overproduction. Those helped to cushion the product against market volatility (Zheng Lintao, 2013). Yet, such efforts clearly can only be of limited effect in terms of protecting small producers against big market fluctuations.

Thus far, the state has not seen much beyond the scope of such administrative interventions that exceptional local governments have exhibited. The specialty coops are supposed to help, but have not (more below). There has been no effort to cope with the problem through semi-governmental, integrated co-ops, such as what was done in Japan-Taiwan-Korea earlier, where small cultivators joined together to cope with the big market: to purchase inputs in bulk at favorable terms, and to organize for the processing of agricultural products, for better information about market demand and supply, and for the marketing of their products (more below). Small peasants in China, therefore, have been much more at the mercy of merchants and big market forces.

The state's main strategy to cope with this fundamental problem of the highly marketized new agriculture has been to resort to the theoretical belief that largescale operations enjoying economies of scale are not only the most productive, dynamic, modern entities, but also the most able to cope with price fluctuations. Therefore, the state's resort, here as in the old agriculture, has been to emphasize the development and subsidizing of such entities. At bottom, it has been the transference of an economic principle from industrial production to agriculture, as reflected in the commonly stated strategy and objective of the "industry-ization" 产业化 of agriculture. To most of the planners, that has meant above all an absolute trust in large-scale production.

Almost from the very start, the policy was to focus on such capitalistic entities, to provide extra incentives and support for the largest among the new agriculture producers-dragon-head enterprises and other capitalist entities. In most recent years, large $(100+m u)$ "family farms," first adopted for grain production (in Songjiang district in Shanghai), then extended more generally, have been added to the list. The overwhelming majority of farms for the new agriculture, however, do not begin to meet that standard of "more than $100 \mathrm{mu}$," set initially for grain farms, thus adding much confusion to just what the policy of promoting "family farms" means. Moreover, the reports from Songjiang never faced up to the issue of high costs (in rent and in hiring labor) of large-scale production but merely relied on ideologized theory to exaggerate the productivity and profitability of the big farms, without seriously comparing them with the smaller, genuine family farms using mainly family labor (Huang, 2014: 186-89; see also Huang Zongzhi, 2014b). 
A dramatic illustration of the blind belief in large-scale capitalist enterprises is documented by a team of researchers, including 15 Ph.D. students, of the Center for the Study of Rural Governance (of the Huazhong University of Science and Technology) 华中科技大学乡村治理研究中心. In “W” province's “ $H$ ” municipality, there have been aggressive efforts in recent years by the local government to concentrate production by pushing massive transfers of land from small peasants to big capitalist farms and firms, such that by the third quarter of 2014, more than half (56.5 percent) of the total cultivated area had been reportedly thus transferred. Despite the local government's claims that those efforts had led to horizontal integration (into labor-hiring large farms) and vertical integration (with the firm providing the processing and marketing of the vegetables), the reality turned out to be that neither had occurred: not the first, because of the high cost of operating with hired labor; and not the second, because of the prohibitive costs for a firm to integrate large numbers of small producers. The entire drive to bring “capital to the village" 资本下乡, therefore, was really just a sham. The local Lüguang (or Green Light) Company 绿光公司 provides a striking illustration: it had tried in 2009-2012 to operate a large farm with hired labor, but lost money and failed. Then it tried to provide processing and marketing services, but that too failed. By the time of the investigation, its 1,520 $\mathrm{mu}$ of transferred-in land had in fact all been re-transferred (re-rented) out to individual peasant households, and after that the firm had merely collected rent and not provided any services for the peasants. (See the summary of the findings in Wang Haijuan, 2015.)

According to the analysis of Wang Haijuan 王海娟, this is a phenomenon that can only be understood in political and not economic terms: the true dynamic driving these kinds of changes is simply the administrative reality that it is far easier and cheaper for the local government to deal with a relatively small number of big firms than to deal with large numbers of scattered small-peasant households. The entire project of bringing capital investments into villages, in other words, led not to any meaningful agricultural development, but only to the attempt to simplify the administrative control of small peasants, through the governmentsponsored and supported capitalist firms (Wang Haijuan, 2015).

But the main propellers of the new agricultural revolution have been in fact millions upon millions of small peasants-simply by opting to engage in such agriculture for its higher market returns. Yet their contribution has been largely ignored by the state. They have received no attention at all in the 13 successive Number One Documents. No real improvements have been made toward helping small-peasant producers develop the vertical integration services they so sorely need, namely processing and marketing, certainly not beyond the simple action of building crude large-scale wholesale markets to help in fuller marketization of the new agriculture. Beyond those, small-peasant producers are left at the mercy of the system of middlemen merchants. Instead of being acknowledged as the main drivers of the new "hidden agricultural revolution," instead of being helped and supported by the state as the mainstay of the new agriculture, they continue to be 
viewed by the state as somehow backward and unreliable, because of their smaller scale. That is a critical error of Chinese agricultural policy of the Reform era.

A particularly revealing example is an investigative report on the situation in Yongnian county, the number 1 "model county" in Hebei province for the new agriculture, mainly of vegetables. Unlike the typical self-congratulatory official and semiofficial reports, this one by a group of basic-level local agricultural cadres is distinctive for "telling it like it is." Even so, the opening and ending of the report are packaged with the usual laudatory and hortatory administrative-ese touting the achievements of the county. The substantive part of the report comes in the middle, though the investigators seem even then to have deliberately used the ploy of speaking through an interviewee rather than in their own voice. Nevertheless, the overall picture is laid out clearly and succinctly. Peasant products must pass through layer upon layer of marketing intermediaries before they can reach the consumer: from the middlemen peddlers and merchants to the wholesale markets of the producing area, to the wholesale merchants, to the wholesale markets of the selling area, and finally to individual merchants and peddlers again, before reaching the consumer. The large wholesale markets (especially those in big cities like Shijiazhuang, Beijing, and Tianjin), it is pointed out, had been built with capital raised from investors, whose expectations for returns to their investment have and indeed must take priority. Hence, there are ever rising fees charged for peasant producers' entering the (wholesale) market, using a stall, and making a transaction. The result is added costs for the peasants, whose net returns can only come after paying the layer upon layer of charges imposed by marketing intermediaries. This is the fundamental structural problem in small peasants' dealings with the "big market." This is why the paradoxical phenomenon of "vegetable growers lose money, yet consumers pay high prices” 种菜赔、买菜贵 has become so pervasive (Li Kai et al., 2014).

According to another report of this same county, also from a local agricultural cadre, another rarity because of its concreteness and critical assessment of things, the biggest local wholesale market (despite the accolades heaped upon this county) is in fact poorly managed and a mess, does not see to peasant interests, and has given rise to the proliferation of roadside "illegitimate markets" 野市场, with many peasants preferring to deal in those, rather than enter into the large wholesale market (Zhang Yongge, 2014).

Among researchers, one major point of view comes from those who insist that Chinese agriculture today is already unmistakably and irrevocably "capitalist" (in terms of "mode of production"), a part of the inevitable worldwide process of "transition" to capitalism under the predominance of the market and of global capital. They do not distinguish the old and the new agriculture. The theoretical reasoning, consistent with Marxist theory (actually, also neoliberal marketist theory) is that "commodification" cannot but lead to capitalism.

Marxist critics are of course correct in criticizing the state for its misguided policy of favoring large-scale enterprises, but they have way overestimated the 
extent of capitalist development. In the case of the old agriculture, as pointed out above, we need to see the extent to which it is still state planned and controlled, more a state-administered agriculture than "capitalist." In the case of the new agriculture, we need to realize that the producers are still predominantly small-scale peasant farms, generally of less than $15 \mathrm{mu}$ (2.5 acres) in size, producing as much out of survival and consumption concerns as of enterprise. To be sure, the small producers assuredly produce under the "exploitation" of merchants, through what we might term "relations of circulation" rather than of production, very different from Marx's conception of "relations of production." In any case, to label a system of small-peasant farms laboring under merchant extraction as somehow "capitalism" is a misleading use of the term.

One reason our Marxist colleagues have tended to overemphasize the role of commodification, perhaps, is the lack of acquaintance with the degree to which agriculture had long been highly commercialized well before the coming of international capitalism. In China during the six centuries before 1950, that commercialization had been based mainly on small-peasant production and on extractions from the countryside of luxury goods (like fine grains, meats, silk thread, fine cotton) for town folk, mainly in the form of rents charged by absentee landlords, with very little reverse flow of urban goods to peasants (beyond subsistence items like soy sauce, salt, and sugar). And it had been driven more by involution (labor intensification to maximize returns from small farms at the cost of diminished returns per unit labor, like switching from rice production to cotton-yarn-cloth or silk cum silk-reeling production, for 18 times and 9 times the labor input, respectively, but nothing like those orders of magnitude in returns), a matter of survival-seeking under the "resource endowment" condition of lots-of-peoplebut-little-land, not simply of enterprise and profit. Furthermore, the market economy that developed had not been one of spiraling rural-urban exchange, in the manner observed and conceptualized by Adam Smith for eighteenth-century Britain, but rather mainly trading among peasants in subsistence goods, of surplus grain for cloth or yarn or the reverse. It would be foolish to base oneself on theory alone, whether Marxist or neoliberal, to project on to all of the world in all periods the same kind of (modern) market economy and capitalist development (Huang, 1990: esp. chaps. 5, 6; cf. Huang, 2016: passim).

As we have seen, some of these scholars have taken the figure of a total of 340 million $m u$ of land transferred up to 2013 as proof of an overwhelming tide of the development of capitalism in Chinese agriculture. But it must be remembered that that figure is just a sixth of the total cultivated land in China, and that the bulk of the circulation of village cultivated land has in fact taken place mainly among small producers, usually neighbors and relatives, among those who have gone off to work off-farm and those who have remained to farm, not from small peasants to big capitalist farmers. The situation has certainly changed considerably in recent years with the local governments' aggressive pursuit of drawing capital to the countryside and encouraging the transferring of land. But it must be remembered 
also that, except for circulation among villager relatives and neighbors, rents for transferred land are often high: e.g., 600 to 1,000 yuan per $m u$, compared to 100-300 yuan per $m u$ among neighbors and kin (e.g., in Liaocheng in ShandongGao, 2014: 238), which has actually been a significant force forestalling capitalist entities from renting more land. That, plus the burden of having to hire full-time workers and supervisors, has severely limited the spread of large capitalist farms. Those are important reasons why big agricultural enterprises have often opted to go into non-labor-hiring contractual arrangements and agreements with small peasants, preferring to deal with small producers through contracts or purchase agreements, while taking advantage of lower-cost peasant subsidiary family labor and its superior incentives for work.

It would be surprising, therefore, if capitalist farms should amount to more than just a fraction of the one-sixth of the total cultivated area that has been circulated. The second decennial agricultural survey in 2006, as has been mentioned above, showed that only about 3 percent of the agricultural labor force were full-time hired workers (or, in terms of cultivated area, just 60 million $m u$ or so) (Huang, Gao, and Peng, 2012). The remainder of the land is farmed mainly by small-peasant family farmers. It would be surprising if that figure should turn out to be higher than 10 percent today, something which the third decennial survey of agriculture, in 2016, should be able to tell us conclusively. In other words, agriculture today remains predominantly small-peasant family farming, not the dragon heads and large capitalist farms favored by some policy-makers and insisted upon as already given reality by some researchers, whether neoliberals who laud the direction of change or Marxists who deplore it.

\section{The Specialty Co-ops Model}

\section{Rhetoric Versus Reality of Co-ops}

In addition to the administrative and laissez faire approaches to agricultural development, the Number One Documents also speak of co-ops, something that needs to be dealt with separately. The Peasants Specialty Co-ops Law 农民专业合作社法 of 2007 (promulgated in 2006 and implemented from July 1, 2007) unequivocally states that co-ops shall be voluntary groupings of peasants producing, supplying, serving, or using the same kinds of agricultural products; and shall be entities that are run democratically ("Zhonghua renmin gongheguo," 2006: Article 2). It further provides that members of co-ops shall enjoy the right of "one person one vote" 一人一票 (Article 6).

This legal conception of the organizing principle of the peasant co-ops shows us immediately that the policy-makers have deliberately modeled themselves on Western-style, especially American, co-ops that are purely economic entities, instead of the Japan-Korea-Taiwan type (of "East Asian" co-ops) that have been from the start semi-governmental entities that have taken over many of the earlier local governmental functions in promoting the modernization of agriculture, 
organized according to the administrative hierarchy of village, township, county, province, and central government. The current specialty Chinese co-ops, by contrast, are intended to operate entirely outside of and separate from the existing governmental hierarchy, as in the United States. In other words, they are intended to be purely economic entities that are entirely separated out from the political and social entities.

The design calls also explicitly for democratic management 民主管理 based on a one-member-one-vote principle. That intent and principle, it must be said, stands out sharply from the rest of the contemporary Chinese socialpolitical-economic context, in which governance is centralized under party-state rule, not democratic in the Western sense of one person one vote for members. In fact, except for village committees, most of which wield little power and control little in the way of resources, virtually no Chinese governmental organization (whether executive [administrative], judicial or legislative), or educational entity, is organized by such a principle, in theory or in practice. The one-person-one-vote type of Western democratic governance, if implemented, would in fact be very unusual for the Chinese institutional environment as it exists today. That means that from the start there has been something unrealistic about the legal conception of specialty co-ops for China. If almost nowhere else in the polity and society are such democratic principles practiced, why and how can small peasants be expected to develop such entities? This dimension of the design for the co-ops, in fact, almost ensures that practical realities would be far removed from their representation.

The legal provisions have in fact rarely been implemented and have led to many phony representations to satisfy the government design. We therefore see many entities actually controlled by their major capitalist investors that pass themselves off as democratic, peasant-controlled co-ops to obtain government approval, tax breaks, and subsidies. A sensible estimate is that 30 percent of all co-ops to date are such “fraudulent” “伪”, “翻牌” co-ops, and no more than 20 percent, almost all small ones, are true to the spirit of the law, with the remainder some mixture in between the two. (For a more detailed discussion, see Liu Laoshi, 2010; cf. Huang Zongzhi, 2015: 27-32.)

Further, by design, these peasant co-ops are intended to be separate from the basic peasant community, the village. They are not meant to be anchored on the village, the natural unit and basis of peasant grouping, nor on the natural or quasinatural administrative entities above the village, as was done in Japan-KoreaTaiwan. Rather, they are meant to be anchored on the shared economic interests of similar individual economic actors joining together in a pure, free market environment - a conception ultimately derived from neoliberal economic doctrine. That basic principle too has ensured that these entities would be far removed from the realities of Chinese agriculture.

By contrast, in the historical experience of Japan-Korea-Taiwan, co-ops have long been semi-governmental entities that took over many of the erstwhile 
functions of local governments. Unlike the design of the specialty co-ops, they have been integrated 综合 ones, involved not only in the purchase and supply of agricultural inputs and the vertical integration (processing and marketing) of products, but also in providing credit to members and being involved in community and governmental affairs of the village, thence upward to participation in the township, county, province, and central levels of the government (detailed discussion below).

It is curious why the Chinese government has not seen fit to follow that JapanKorea-Taiwan model, which has been used historically to good effect. Perhaps it is because such peasant- and community-based associations would be reminiscent of China's now out-of-favor collectivized agriculture, in which villages were organized into production teams and brigades that encompassed political-social as well as economic functions. Instead, in the current ideological and discursive environment of China, it is the Western, especially the American-style "specialty co-ops" model, in which the economic is entirely separated out from the socialpolitical, that has seemed more desirable. ${ }^{4}$ But the American model's disregard of farming communities is largely the consequence of its objective environment, in which large farms separated from each other by considerable distances have pretty much precluded the formation of closely knit farming communities like Chinese villages. Artificially applied to China, such a model amounts to a denial of the basic Chinese social-political reality of village communities.

The inability of Chinese co-ops to obtain credit from financial institutions has been another crippling factor. It is clear that the planners, from the start, intended to make credit available to peasants, such that the successive Number One Documents have all contained such a declared intent, along with instructions for various state banks to make credit available to peasants. But those banks today in fact operate by the (nearly universally employed) market principle of requiring readily marketable real property as security for loans, so that they can recover their loans if the borrowers default. Peasants have lacked such readily marketable property. Thus the declared intent in the 13 Number One Documents to make credit available to them has been mostly just talk, of little actual consequence.

The Number One Documents of 2015 and 2016 have been concretized to the extent of specifying three separate kinds of relevant real property 三权（分置） that apply to peasants and villages: peasants' home/house (but without the land, which belongs in theory to the collective), peasants' use rights over responsibility land, and the collectively "owned" land of the village. However, the first two rights, belonging to the individual peasant household, are of relatively limited liquidity (marketability) and value in the present institutional environment. Unlike urban real estate, with a wide market, rural homes only have a very limited market, since only a small number of people would be interested in purchasing a particular

\footnotetext{
4 On the separation of the economic from the social-political in present-day specialty co-ops, see Yang Tuan, 2013.
} 
home in a particular village. The same applies to a particular household's responsibility land up for rent. As for the collectively "owned" land in a village, it cannot in fact be bought and sold without the special permission of the government (which, in the final analysis, is the de facto if not de jure owner of all land in China). The difficulty for financial institutions therefore is: in the event of default on a loan, it would be difficult for the bank to sell off such "property" to recover its loan. Hence, despite 13 years of declarations and calls for more credit availability for rural China, the reality is that nothing substantial has happened and everything still remains just in the proposal stage. The most recent (2015 and 2016) Number One Documents are still merely at the stage of looking only to possible "testpointing” 试点, still without any clearly defined usable path of actualizing credit availability for peasants and villages ("Zhongyang yihao wenjian," 2015, 2016).

In the Chongqing experiment commissioned by the central government in 2008, it was thought by the local Chongqing leadership for a time that a governmentestablished “land certificate exchange” 地票交易所 enabling trading in peasants' residential plots 宅基地 could enable peasants to share in the gains of appreciating land values from urban development and also break through the constraint of peasants' lack of real property that can be capitalized on or used as security for bank loans. But that approach has had only limited effect, because peasant residential plots are in the present institutional environment by law not the property of individual peasants but rather of the collective which, in actual practice, can only be bought or sold with the permission of the government. Such land is in fact not readily marketable to be able to serve as security for loans from financial institutions. In the actual implementation of the Chongqing government's effort to extend financial credit to peasants, therefore, in fact only (some) peasant houses, not peasant residential plot land, have been accepted by financial institutions as security for loans, and that of necessity on a limited scale because of their limited marketability. The original intent of trying to extend financial credit to peasants on the basis of their residential plots has therefore stalled (Huang, 2012: 618-19; cf. Huang Zongzhi, 2014a: 367-68).

In hindsight, we can see that Chongqing's land certificate exchange was in fact not about the exchange of landed property (residential plots) per se, but rather only about trading in central government permits for units of development landbecause the restoration of one unit of residential plot to cultivation, certified by the government, would enable the local government or developer to gain permission for an equivalent unit of land for urban development 建设用地, under the policy of "linking increases and decreases in rural and urban development land" 城乡建设用地增减挂钩. What is marketable is those permits, not the residential plots themselves. Thus have peasants remained largely outside the scope of credit provided by financial institutions.

Despite the declared intention of the successive Number One Documents to make credit available to peasants, therefore, there has been a great hiatus between intent and practice. The fact is, banks are unwilling to accept peasant use rights or 
homes as security because of their limited marketability. As a recent study has demonstrated, where local governments have tried aggressively to develop such credit for peasants, as in Chengdu, the municipal government itself has had to set up a fund (of 30 million yuan) from its own revenues to back up loans secured by peasants' land use rights, absorbing 80 percent of the risk and leaving the banks to carry just 20 percent. In another municipality studied in detail ("S" municipality) by this group of investigators, they have found no example of loans secured only by use rights over land. The outstanding loans have in fact been based either on bundles of different securities (including other assets and the good credit standing of the borrower) or, more often than not, have been guaranteed by an intermediary third party (firms organized for the purpose, or else the government, as in Chengdu). The fact is that under the present property rights system, peasant use rights have simply not been acceptable as security for loans, by the logic of the financial market (Wang Defu, 2016). That applies also, by extension, to co-ops that have transferred in or pooled such use rights of their members.

It is not surprising, therefore, that contrary to official rhetoric and claims, the development of co-ops in China to date remains modest at best, and dismal at worst. By official representation, many co-ops have sprung up since the implementation in 2007 of the Peasants Specialty Co-ops Law. Ostensibly, the new surge of 1.21 million co-ops involve 90 million peasant households as members, or more than a third (34.6 percent) of all peasant households. On the surface, such figures seem to suggest an irresistible tide about to take over the Chinese countryside. In fact, however, even by the official tallying, only something like 10 percent of the co-ops are deemed to be "good" co-ops ("Rang nongmin hezuoshe yunxing genghao shili gengqiang," 2014). And it is clear that co-ops that are actually peasantcontrolled and serve peasant interests are almost all poorly capitalized, their "capital" amounting to just what they are able to collect as membership fees. The truly powerful entities are the dragon heads and big farms passing off as co-ops, which own readily marketable assets (e.g., farm machinery, facilities for infrastructure agriculture, processing and storage facilities, and so on) that banks are willing to accept as security. Only those fake co-ops are able to raise capital and provide substantial vertical integration in processing and marketing for peasant production; in fact, many of the largest co-ops are organized by just such processing and marketing firms to begin with. Such so-called co-ops are in reality capitalist enterprises, and peasant co-ops only in name. Despite the 13 successive Number One Documents' declaration of support for co-ops, therefore, the operative reality is that genuinely small-peasant-based co-ops faced severe handicaps. In an environment in which the state actively supports capitalist entities, the lack of comparable support amounts in effect to discrimination (Huang Zongzhi, 2015).

Investigative reports about co-ops even in a (national) model county like Shouguang provide illustrative concrete evidence about the supposed new co-op tide. According to one report, in 2012, many of the recently arisen co-ops since the 2007 Specialty Co-ops Law existed only in form, not substance. As an example, in 
one locale investigated, of 61 registered co-ops, 24 turned out to have no office; in another locale with 40 registered co-ops, only 13 were actually operating; in yet another with 17 registered co-ops, only nine actually operated (Chen Yanxia, 2012).

In the (provincial) model county Yongnian, the situation is largely similar to that in Shouguang. The 236 supposedly thriving specialty co-ops have in fact not helped at all in mediating between the small peasant and the big market. Smallpeasant producers, as we have seen above, still must cope with the multi-tiered layer-by-layer charges imposed by merchants big and small, without the help of co-ops, thus greatly enlarging the price differential between what the consumer must pay and what the peasant producer actually obtains, to create a situation in which "vegetable growers lose money, yet vegetables are expensive." As the basiclevel agricultural official succinctly put it, in Yongnian co-ops simply "have not had much effect" (Zhang Yongge, 2014).

The severing of the specialty co-ops from village communities and local governments, moreover, has meant a complete segmentation between the peasants' pursuit of economic interests and their political-social communitarian loyalties. Absent a community base, there is nothing to involve and motivate villagers to join together for community interest. Under the specialty co-ops, too often there is nothing but each person's pursuit of individual self-interest, something which the current institutional environment, with state policies favoring and glorifying private enterprises, has done much to encourage. And the state's financial institutions, unwilling to give peasants credit, have in effect built an insurmountable barrier against capital formation by small peasants and their co-ops.

That is one reason why in so many villages elections have been of only minimal interest for the atomized villagers, engaged and concerned as they are mainly in the pursuit of their personal economic interests. In the great majority of villages there is little in the way of collective assets beyond their theoretical (but not practical) ownership of the village's land, and hence little chance for those who control the village government to enrich themselves, and thus village elections have often been characterized by a general lack of interest or participation. Only in villages with significant usable collective assets (e.g., forest land or sizable development land) have elections drawn much interest, but then often rich and powerful individuals or clans manipulate and cheat (including buying votes) their way into controlling the village government for their own gain. (See the summary discussion in Wang Xiaolu et al., 2015: 301-4.) Those are logical consequences of the present institutional environment, in which community-based, genuine peasant co-ops can only develop with great difficulty.

That does not mean, however, that there are no counterexamples among co-ops in China today. In one outstanding example, the $\mathrm{Pu}-\mathrm{Han}$ (of Puzhou township 蒲州镇 and Hanyang township 韩阳镇) Co-op of Yongji city in Shaanxi province 陕西省永济市蒲韩农协 has been carefully tracked (and therefore comes with rich written materials) by the Social Policy Research Center of the Academy of Social Sciences 中国社科院社会政策研究中心. It had begun in Zhaizi village 
寨子村 (growing mainly the new agriculture products of vegetables and fruits) in 2004 as an entity to provide agricultural inputs for peasants, taking orders from peasants of the community and purchasing inputs for community members as a group. That entity had succeeded in spreading quickly from this one village to encompass five chain-stores, serving 43 villages and more than 3,800 households.

Along the way, it developed a co-operative credit society, by collecting a 2,000 yuan membership fee and then extending loans to members, varying from 5,000 yuan or less, up to between 20,000 and 30,000 yuan. The co-op had begun by collaborating with a credit firm that operated by returns-maximizing capitalist principles (as opposed to an ideal of serving the membership). But that collaboration broke down because of the fundamentally opposed principles of the two sides. After the breakup in 2012, the co-op has nevertheless managed to expand its credit operations to a total capital of 32.8 million yuan, extending loans to nearly 2,000 outstanding accounts. It has been a profitable operation (in part because of the interest charged for loans, at local market rates, ranging from 6 percent for small loans and up to 18 percent for larger loans) and now constitutes the main source of revenue for the co-op. All this has been accomplished without any state subsidies, or even just approbation; indeed, the co-op at one point even had to face a lawsuit (brought by its erstwhile partner firm charging it with "illegal collection of capital” 非法集资), but it managed to prevail in the end (with the help of this particular local government). The co-op has also extended into provision of technical guidance and support, processing of products, and marketing, in addition to providing credit to members (Wang Xiaolu et al., 2015). But, of course, it is clearly still of just modest scale and influence, nothing like the co-ops in Japan-KoreaTaiwan, which have successfully extended from villages up through the governmental hierarchy, all the way to the national level.

The example of the Pu-Han Co-op, despite its departure from the official model of a "specialty co-op," suggests that if such co-ops were to enjoy official approbation and support, they could potentially develop in the direction of co-ops of the JapanKorea-Taiwan model, possibly even amalgamate with official entities like the (now only rather insignificant) supply and marketing stations (more below) and perhaps even other entities serving peasants and agriculture. In addition, we know that even under the present misconceived specialty umbrella of co-ops detached from village communities, a large number of co-ops have been formed through the leadership of village cadres (39 percent of all co-ops in 2011, according to an investigation said to have been submitted to the Party Central-Huang Jikun, 2011), and many of them are therefore unavoidably linked to the village communities.

Such co-ops could fill the vacuum that small households are now left in. And they could come to propagate an entirely different principle and mode of operation from present institutions, to work by the principle of a common or greater good, a kind of communitarianized self-interest, rather than just simple individual self-interest. That would help greatly in the reinvigoration of the increasingly atomized village communities. 
That there are, despite an inhospitable institutional environment (namely, lack of unequivocal state approval for such a form of community-based co-op organization, inability to obtain credit, handicapped competitive position vis-àvis capitalist enterprises that enjoy strong state support and subsidies, and lack of official approval for organizing cooperative credit institutions), sizable numbers of co-ops serving peasant interests and managed by peasants suggests that this is a wide road of considerable potential. As Yang Tuan, Wang Xiaolu, and other representative scholars of the group Beijing nonghe zhi jia 北京农禾之家 (Beijing Association of Integrated Peasant Co-ops), now encompassing 108 co-ops in 18 provinces (Yang Tuan et al., 2013), have pointed out, such co-ops would help to advance not only the interests of their peasant membership, but also help to reinvigorate the village communities that in the past thirty-plus years have declined so drastically.

\section{The Neglect of Peasant Initiatives and Interests}

Overall then, the problem with the three major models of rural development in the Reform era has been that the state has limited itself to either an overly neoliberal laissez faire approach or an overly planned-economy administrative approach to development. Those are the fundamental ideologies that have underlain the state's approach to agricultural development. Among policy-makers, the two sides have been able to agree only on a very limited number of things, one of which is the misguided belief that economies of scale are synonymous with modernization, expressed variously as (capitalist) dragon-head enterprises, big entities, or large "family farms," without consideration of the initiatives and contributions made by the small producer nor the basic realities of the new agricultural revolution. The state has given its active support mainly to the largest producers, to the disregard of the small producers, who have in fact been the main drivers of the hidden agricultural revolution we have witnessed in the past thirty-plus years (Huang, 2016; cf. Huang Zongzhi, 2014a, 2010).

There are multiple reasons for the state's failure for quite some time to grasp the real nature of that new "hidden" agricultural revolution. The first is a matter of habits of mind. The old presumption that agriculture equals above all grain production dies hard. So too does the preoccupation with grain security, born of the long background of historical experiences with famine and hunger. So too with the belief in economies of scale, an article of faith of both neoliberal and Marxist perspectives. What the state has not grasped clearly is the historical reality of China's "basic national condition" 基本国情 of "lots of people and little land” 人多地少, in contrast to the West's (especially the New World U.S.'s) "lots of land and few people." That has meant the necessity of small farming (lest vast numbers of peasants be disemployed), and the consequent need for institutions different from those of the West to help the small peasant cope with the environment of an ever larger, ever more interlinked and globalized "big market." For 
those and other reasons, many have not grasped the reality of the "hidden agricultural revolution" propelled by small peasants (Huang, 2016; see also Huang Zongzhi, 2014a, 2010).

The problem lies also with the statistical data, in which the focus has long been on output per unit land by weight, rather than the marketized reality of output value. Most people continue to think of agriculture only in the narrow sense of the “small agriculture" 小农业: i.e., crop production 种植业. Animal husbandry data are placed under the category of $m u$ 牧, which misleads us to think in terms mainly of pastoral animal husbandry, rather than animal raising by small farms. And fishery 渔 mainly of lake-river-ocean fishing, rather than the fish ponds of small family farms. There is also much confusion with regard to vegetables, in which the big change has not been increased output by weight but rather the shift toward ever more high-value leafy green vegetables, as opposed to cheaper root vegetables. The two remain largely indistinguishable in the data. The new "infrastructure farming" of hothouse and tented vegetables as opposed to open-air vegetables, and of animal raising in concentrated structures rather than the scavenger pigs of old, is not clearly separated out and hence easy to miss, leading to the tendency to overlook the giant reality of the new-style agricultural revolution (Huang, 2016; see also Huang Zongzhi, 2014a, 2010).

On a deeper level still, perhaps, is the continued predominance of the two development ideologies that are both predicated on historical experiences very different from China's. The newer of the two is the neoliberal one that holds that "rational" individuals pursuing their self-interest in a freely competitive market is the ultimate dynamic for (capitalist) economic development. Hence the decision by the authors of the 2007 Specialty Co-ops Law to model themselves after the United States experience. There are those who would add, on the basis of the influential new institutional economics, that private property is the sine qua non for the release of individual entrepreneurial energies, hence the persistent arguments by many for the complete privatization of land in China and the termination of the household responsibility system. Most of all, there is the belief that market forces must lead to large entities, hence the insistence, not just by neoliberals but also by Marxists, on favoring and focusing on those, to the neglect of small-peasant farmers.

The problem of such a scheme is that it bears little resemblance to the history and realities of Chinese agriculture: six centuries of marketized agriculture set the background not for the development of capitalist agriculture but rather for a gigantic social crisis and the twentieth-century Chinese social revolution. It also disregards the village communities that make up the basic units of Chinese society, complete with their deep-seated notions of village membership that distinguishes insiders from outsiders, use of fictive kinship among community members, the practice of community mediations of disputes, and, in some areas, common efforts for cooperation in production, or self-defense and water control, or construction and maintenance of temples, and so on (Huang, 1990), imagining instead an American-style countryside without village communities. 
The other ideology, on the other hand, had led to the old socialist planned economy, collectivized agriculture, and the persistence today of their legacies. We have seen how, regardless of the hegemony of the new neoliberal economics discourse (most clearly seen in the nation's economics departments, where the new neoclassical textbook economics is practically universally taught, replacing completely the old Marxist political economy), old habits of mind and practice die hard. We have seen how, faced with new pressures and problems, officials have naturally turned back to planned-economy-like thinking and methods, and how, when new market problems emerge (such as the fact that global prices for grain are now lower than those in China) and issues of national (grain) security emerge, the old administrative approach once more takes over. But the problem with that approach, in the present day as well as in the Mao Zedong era, is that it allows little or no room for peasant initiatives and creativity.

Neoliberal and Marxist mentalities and habits can be seen as making up two major factions among the nation's officials and leadership that are engaged in a continual tug of war, such that policies are often the result of tenuous accommodations and compromises between the two, and such that the easiest policies to adopt and enact are those on which the two sides, despite their sharp differences, can agree. Hence the fundamental agreement and reliance upon scale economieswith the deep-seated assumption that the weaknesses of small-peasant production can only be overcome by large-scale production enjoying those economies. Hence the ready agreement by both sides to support and promote dragon-head enterprises and other large farms. The decisions of the top leadership are arguably born mainly of such a dynamic, though we must not overlook the co-presence of both ideologies not just within the Communist Party as an organizational entity but also within individual members/leaders of the party. Regardless, we have seen above how misguided an absolute belief in scale economies is, as shown in the record of Chinese agricultural policies in their obsession with supposed economies of scale, first with large-scale collective farms, and now with the dragon heads and big farms, including supposed "family farms" of over $100 \mathrm{mu}$.

The laissez faire specialty co-ops model favored today can be seen also as something born of that mix of theories and persuasions, with the addition of nativist sentiments. To some Marxists, co-ops seem somehow closer to socialist ideals than simple capitalism (though other Marxists would reject it completely for the lack of a class struggle and production relations perspective). To some neoliberals, co-ops, especially American-style specialty co-ops, seem an acceptable second-order institution that is compatible with marketism and capitalism. Finally, to some nativists, peasant co-ops seem to come with a laudable amount of nativist populism. The crisscrossing mixes and tugs among those three views, perhaps, is how the construct of "peasants specialty co-ops" emerged, granting as it does something to each of the three persuasions: in its concern for supposed economies of scale, laissez faire marketism, and cooperation and nativist populism.

The key weakness of the administrative model is above all its lack of understanding of and willingness to rely on the initiatives and creativity of the 
small-peasant family farmer. The real propellers of the new hidden agricultural revolution are millions upon millions of small peasants who have turned to higherreturn new agriculture: in tented/hothouse farming, especially of higher-end vegetables, fruit orchards, infrastructure chicken raising, fish farming in small ponds, and so on, all on just a few $m u$ of land. There are also those who have combined animal husbandry with the raising of feed crops (e.g., the corn farm with a few dozen heads of pigs, cattle), rarely on farms of more than $15 \mathrm{mu}$. But the administrative model does not acknowledge such peasant contributions. When the controlling impulses of the administrative model take over, it tends to become commandist without regard to small-peasant interests, as has happened with the aggressive pursuit of double-cropping of rice.

The key weakness of the neoliberal marketist model, on the other hand, has been an unrealistic picture of peasants as "rational economic actors" whose enterprising pursuit of profit in a market environment would of necessity lead to the development of large-scale capitalist agriculture. Most peasants in the new agriculture in fact operate miniscule farms (by Western standards), by their own labor and without hiring labor. Many of them have been driven originally by subsistence needs to maximize output and returns on their few $m u$ of responsibility land. And many have paid for their investments (in fixed structures like plastic tents and in liquid capital inputs like chemical fertilizers and improved seeds) not by accumulated capital but with wages earned by family members working off-farm as semiproletarians. Many, moreover, have been motivated by the drive to build a dignified 体面 home in the community, to send their children to college, to host a dignified wedding or a dignified funeral, and so on, rather than by the capitalist drive to maximize profits, accumulate capital, and expand the scale of their farm production. Most of these small farms and small peasants are very different indeed from the rational economic man turned capitalist entrepreneur imagined by neoliberal doctrine, and have therefore lain outside its scope of vision. Neoliberals, no less than Marxists, have therefore also been unaware of the realities of China's recent agricultural revolution and its real developmental dynamics.

Even the modernizing development of the old agriculture of grain farming, it must be pointed out, has been powered similarly by "appropriate scale" smallpeasant farmers, operating farms of 20-50 $\mathrm{mu}$ in the main, rather than the statepreferred large-scale farms. Those new "middle peasant" farms, based on peasants who have taken advantage not only of the historic conjuncture of a decline in the numbers of people entering the labor force each year (due to the decline in birth rates from the vigorous implementation of the one-child policy beginning in 1980) and greatly increased off-farm employment that have together increased the average cultivated area per labor unit from a low of $5.9 \mathrm{mu}$ up to $10 \mathrm{mu}$ today, but also of renting in the land left fallow by kin and neighbors working off-farm. These "middle peasants" have in fact become the mainstays of China's grain economy and their rural communities. If we add to these middle peasants other smallerscale peasants who have been able to supplement their farm incomes with off-farm employment, and who have modernized their farms by purchasing tractor 
plowing-planting-harvesting services, or new chemical fertilizers, improved seeds, or (labor saving) weed killers with their wages, both in the old and the new agriculture, thereby attaining mid-level incomes, the combined total in fact amounts to a majority of many village populations.

When we read through all of the Party Central's Number One Documents of the past 13 years, what is perhaps most striking is the detailed attention to the multifaceted administrative role of the state, along with expositions of how the state will favor and support the so-called new entities of dragon heads, large-scale enterprises, big family farms, corporatized co-ops, and the like, with no mention at all of the initiatives, creativity, and contributions of the small-peasant producer. The only exception is the 2008 Number One Document, which, in one particularly striking passage - striking because it is so out of character with the main tone and message of all the others - actually said, "we must stabilize and perfect the basic rural management system, continue to deepen rural reforms, trigger the release of the creative capacity of the hundreds of millions of peasants, to provide thereby the strong dynamic for rural social-economic development" ("Zhongyang yihao wenjian," 2008: section VI [emphasis added]). That passage, however, was not elaborated and therefore reads like mere rhetoric without substance. This, I believe, is the crucial neglected aspect in all 13 of the recent Party Central's Number One Documents on agriculture.

In short, what some decision-makers, planners, and scholars have not grasped is that the small producers have in fact been the true subjects and drivers of the new hidden agricultural revolution. Hence, they have not seen what those small farmers, especially those in the new agriculture, need more than anything else: vertical integration for processing and marketing of their small and scattered products. For the industry-like vertical dimension of processing and marketing of farm products, scale economies are indeed essential, but not for the horizontal dimension of farming. The planners can envision only horizontally integrated large-scale production, along with state administration and/or capitalist firms for vertical processing and marketing, but not an alternative to those, one that would be based on small-peasant farming along with processing and marketing by peasant-based co-ops that truly seek to serve the interests of the peasants.

\section{A Different Alternative: The East Asian Historical Experience}

The suggestion here of an alternative path may seem to some just a romantic dream and indeed if we had no historical precedent to cite in support of the argument, it would be no more than a "vision" based just on little more than a fuzzy critical sense toward both the capitalist path and the earlier Soviet and Chinese planned, collective agriculture path.

This is where the historical experience of peasant-controlled co-ops that saw to the benefits of their members - such as those that played a large role in JapanKorea-Taiwan during their periods of agricultural development comparable to 
present-day China's, especially the 1960s to the 1980s-becomes crucially important. Those co-ops had emerged as a coincidence of history: Japanese local administration had from the late Meiji period on taken up agricultural modernization as its main responsibility and function. That legacy had been extended to Korea and Taiwan through colonial occupation (Kang and Ramachandran, 1999; Ho, 1968; cf. Huang Zongzhi, 2015). It is one of the ironies of history that that tradition should then have come under American influence through American occupation, most especially through another coincidence-of the decisive influence of a group of occupation officials who identified closely with the legacy of President Franklin D. Roosevelt's New Deal policies (Cohen, 1967). Under that influence, land reform favoring the small owner-cultivator was enacted and landlordism effectively ended—farm sizes were limited to $45 \mathrm{mu}$ (3 chō 町 in Japanese), and outside capital was not allowed to purchase farm land. Further under that influence, co-ops under the control of peasant members rather than state officials were established to become the key semi-governmental institution of villages and townships, taking over many of the functions and resources formerly administered by the local governments. From that base, the co-ops were extended upward along the bureaucratic hierarchy layer by layer to encompass higher-level local governments, on up to the provincial and, finally, the central levels as well (on Japan, see Kurimoto, 2004; Esham et al., 2012; and Moore 1990; on Korea, see Ban, Moon, and Perkins, 1980; on Taiwan, see Fei et al., 1979; for detailed discussion and other secondary literature, see Huang Zongzhi, 2015).

Those co-ops, peasant run and government mandated and supported, took over the crucial functions necessary for a small-peasant farm economy: to provide inputs at the most reasonable prices by purchasing them in bulk at the best discounts, provide credit to needy and innovative members, lend a concrete focus to community activities, and provide the most cost effective processing of agricultural products. They also organized marketing of those products, to the extent that the Japanese Nōkyō 农协, the national co-op, became an honored brand name in itself. All those functions were performed by the co-ops in lieu of the state, capitalist firms, or merchant entities. The result was to ensure that a larger proportion of the gains from the higher-value, marketed products devolved back to the peasant producers. (See especially Moore, 1990: 152-54, 166; Esham et al., 2012: 946-48; Huang Zongzhi, 2015.)

The historical coincidence that led to the births of such co-ops created a situation in which just about every peasant could see how the co-op was to his/her advantage: for obtaining inputs at lower prices, for organizing the processing of their farm products and then marketing those, and hence skipping the merchant extractions that today so plague Chinese small farming, and also for giving them organized expression of their interests in national politics, to the extent that a major activity of the co-ops became annual lobbying (in the summer) of the government to set higher rice prices. An understanding of those dimensions of the co-ops enables us to see why and how the co-ops of Japan-Korea-Taiwan were able 
to enjoy the active and willing participation of the great majority of peasants, even though membership was strictly voluntary. (See especially Moore, 1990: 156-57, 165; cf. Huang Zongzhi, 2015.)

At the core of all this was peasant initiative as the subject producer and marketer of its produce, not as the object of control by state administration nor the hired worker of the capital-owning firm. That in turn went a long way to improving the livelihood of the small peasants along the path of increased labor productivity and returns (which is what should be the core meaning of "modernization"), thereby truly reversing the long-standing gap between city and countryside, the urban middle class and the peasant. All this is attested to by the Gini coefficient measures, according to which "capitalist" Japan, Korea, and Taiwan have ironically ended up far more socially equal than "socialist" China. By the American CIA's 2015 data: Japan's was 37.6 (the latest data being for 2008), ranking number 65 among 141 nations (and locales) tabulated; Korea's was 31.1, ranking number 29; and Taiwan's was 34.2, ranking number 47 . China, by contrast, has a score of just 47.2 (2013 data), ranking number 114 of 141 nations of the world in terms of social equality. It is one of the stark ironies of history that erstwhile "socialist" China should have become one of the lowest ranking in the world in terms of social equity and development, when it had been one of the most advanced just a few decades earlier (CIA, 2015; cf. Huang Zongzhi, 2015: 27).

To be sure, the Japan-Korea-Taiwan economies today have only a low percentage of their populations engaged in agriculture and are in that sense rather different from China. But there can be no mistaking their sharing in the history of (China's basic national condition) of lots of people and (relatively) little land, and the consequent longer persistence of their small-peasant economies, in sharp contrast to the West European and American historical experiences. There can be no doubting the contributions that co-ops made in Japan's development, especially in the 1960s to 1980 s period, the "golden period" of its agricultural development - a period in which in terms of the proportion that agriculture occupied in its gross domestic product (10 percent in 1965) and of its per capita GDP (US\$10,787 in 1985), it was fairly close to China today (Huang Zongzhi, 2015: table 2, p. 22). Co-ops helped greatly in preventing the formation of a large underclass of peasants in an economy dominated by capitalist industry, setting the basis for its relatively favorable Gini coefficient measures today. The much smaller size of Japan-Korea-Taiwan than China, of course, made it possible for them to bring their agricultural labor force down to well below 10 percent of their total labor force within just a few decades. China, by contrast, is looking at a much longer period of the strong persistence of its small-peasant economy.

Today, a good beginning would be to acknowledge the contributions that have been made by the hundreds of millions of peasants who have provided not only the labor force for China's rapid urbanization, but also the major dynamic for the rise of the new agriculture as well as the significant modernization even of grain farming. If the planners were able to place peasant accomplishments and interests 
rather than state strategies and policies above all else, it would become obvious that the best way to harness peasant energies and initiatives is most certainly not to disregard them, much less to go against them, but rather to do everything possible to encourage and support those initiatives and achievements.

The problem with past approaches to co-operativization has been both doing too much and too little. Early co-operativization in the People's Republic had quickly given way to an excess of control, of authoritarian, commandist planning, the most extreme form of a state-administered model of development. That was followed in the Reform era by the extreme reaction of dismantling the collectives completely in one fell swoop, with excessive trust in the new ideology of neoliberal laissez faire marketism. Yet the state soon found that market mechanisms and atomized peasant farming alone would not do in grain, and has therefore fallen back on the administrative model, to support small farms and provide them with processing and marketing services, and also stabilize prices, though also along with an unrealistic policy favoring big farms. As for the specialty co-ops now touted by the state, they have in reality been more talk than substance, misguided as they are by the U.S. model. The mistake, in part, has come also from some advocates of co-ops themselves who, in light of the problems of the past collectives, have insisted that co-ops be developed entirely through peasant initiatives under a laissez faire marketism model. What those advocates have overlooked is that in China's Reform environment, in which the state continues to play a powerful and overbearing role, for the state to do little or nothing is tantamount to the state's discriminating against co-ops, all the more so given the state's aggressive administrative support for the new capitalist enterprises.

At present, the state has seen fit to separate out specialty co-ops completely from village communities and their political organization. This approach has definite historical roots. In part, it stems from the idea that village-community-based co-ops might be reminiscent of collective brigades of the Mao Zedong era, and no one wants to call upon that tradition in this Reform era. But in Japan-KoreaTaiwan, we have seen, the integrated peasant associations 综合农协 were all built upon the structures and frames of the village communities and the preexisting local governments, whose main mission had been to promote agricultural modernization. They took over many of the technical (agricultural extension) and inputs and credit support apparatuses of the government, which in turn ensured eager and nearly universal voluntary peasant participation and support. That kind of approach, if adopted in China, would clearly be something that would likewise gain the support of almost all peasants.

In addition, linking the co-ops to existing peasant village communities would give them an institutional and social basis the specialty co-ops do not have. Ties among villagers of the same community, though much weaker today than before the Reform era, remain stronger than ties among atomized producers, even if they share the same specialty products and needs. The latter comes from the American model, based on an objective environment in which there have been no village 
communities comparable to China's to speak of, and also on much more highly enterprise-ized farms than China's small producers. But in China, the village remains still a basic social (and administrative) unit of society. It simply makes no sense to disregard it by imagining China to be just like the United States. This is an example of where ideologized theory, both neoliberal and Marxist, has caused planners to think either in terms of capital, the market, and scale economies only, or in terms of class relations and scale economies only, rather than village communities, which remain a basic reality of rural Chinese society.

Today, the basic institutional framework, like elected village governments, is already in place and ready to be drawn upon. And, of course, also the natural community of the village. It is a stark irony that American occupation officials who identified with the Roosevelt New Deal could rise above simplistic imitations of the specialty co-ops American model, first in Japan and then in Korea and Taiwan, but Chinese officials today, in their eagerness to copy the United States, have allowed ideological constructions to replace basic Chinese realities.

Allowing co-ops to serve as the depositories for peasant savings, as happened in Japan, would help lend them financial substance and power, instead of having to rely only on membership dues. That in turn would help build the foundations for what could thence eventually be the county, provincial, and national-level organizations based on peasants and villages, as happened in Japan, to provide the institutional frame for larger financial institutions and processing and marketing services, as well as peasant input into national policy making, for the protection and furthering of peasant interests, something that also happened in Japan. That would help overcome China's "sheet of loose sand" problem, articulated a century ago by China's early revolutionaries, something that has come back today to plague China once more.

The March 2015 directive from the State Council on deepening reform of the supply and marketing stations ("Zhonggong zhongyang guowuyuan," 2015) shows that some among government policy-makers have now given thought to bringing those government entities and the peasants closer together, of developing those into not only the supply and inputs stations and stores, but also a source for credit for peasants. Indeed, there is even mention of possibly turning control over to the peasant members. Yet, as with most Chinese official documents of this era, there is simultaneous mention of using those entities to develop "enterprises," and also of developing capable state civil servants 公务员 to serve the ruralities and agricultural development. The danger of such a murky mix of ideas, of course, is that what happened in the 1950s may well happen again: what were originally intended as peasant supply and marketing co-ops were quickly bureaucratized into state administrative organs. But conceptually at least, the idea has been advanced of developing peasant organizations that would merge state organs into peasantbased co-ops, and of a possibly viable alternative form of rural credit.

What is needed in rural policy today is first, to recognize and acknowledge what peasants have already contributed to rural development; second, for the 
state to implement an institutional framework that would more effectively help foster peasant cooperation, most especially by turning over many of the resources and functions for agricultural development to community-based and peasantcontrolled co-ops; and third, for the state to continue to attend to macro-level strategic planning, and leadership and support at the provincial and central levels for upper-levels of the co-op organizations, including their national credit institution and their interactions with the global economy, as was shown in Japan's coops based national Nōrinchūkin, already in the 1980s one of the largest (and globalized) banks in Japan (Huang Zongzhi, 2015: 22).

Such an approach would combine the best features of the three current models. The administrative model in the old agriculture shows well what the government can do in positive ways; the laissez faire marketist model shows how market mechanisms have harnessed peasants' initiatives and creativity (including taking on employment off-farm); the co-op model, finally, demonstrates the direction that an alternative to simple capitalism and simple planned economy can and should take. China could become the example of an alternative, third road to rural development in developing countries where the small-peasant economy will yet remain for a long time to come.

\section{References}

“2011 nian guojia zhichi liangshi zengchan nongmin zengshou de zhengce cuoshi” 2011年国家支持 粮食增产农民增收的政策措施 [The state's policies to support expanding production of grain and increasing incomes of peasants in 2011] (2011). http://www.moa.gov.cn/fwllm/jjps/ 201103/t20110328_1956244.htm (accessed April 6, 2016).

Ban, Sung Hwan, Pal Yong Moon, and Dwight H. Perkins (1980) Rural Development: Studies in the Modernization of the Republic of Korea, 1945-1975. Cambridge, MA: Harvard Univ. Press.

CIA (2015) "Country comparison: distribution of family income-Gini index." https://www.cia.gov/ library/publications/the-world-factbook/rankorder/2172rank.html (accessed March 20, 2015).

Chen Yanxia 陈艳霞 (2012)“寿光市农民专业合作社发展壮大的几点建议及对策”(Some suggestions and countermeasures for the development of peasant specialty co-ops in Shouguang city). 商场现代化, 9月, 总 695期: 17.

Cohen, Theodore (1967) Remaking Japan: The American Occupation as New Deal. New York: Free Press.

“Dasuan deng caijia yu guoshanche kunju; zhongjianshang chaozuo jiage fan shibei” 大蒜等菜价遇 过山车困局中间商炒作价格翻十倍 [The price of garlic and other vegetables meets up with the predicament of a roller coaster ride; middlemen merchant speculation makes prices jump tenfold] (2011) China Central Television 东方时空, June 29.

Esham, Mohamed, Hajime Kobayashi, Ichizen Matsumura, and Arif Alam (2012) "Japanese agricultural cooperatives at crossroads: a review." American-Eurasian J. of Agriculture and Environmental Science 12, 7: 943-53.

Fei, John C. H., Gustav Ranis, and Shirley W. Y. Kuo (1979) Growth with Equity: The Taiwan Case. Washington, DC: World Bank (by Oxford University Press).

Gao Yuan (2014) "Large farms vs. small farms: grain production in northwestern Shandong." Rural China 11, 2 (Oct.): 222-43.

Ho, Samuel (1968) "Agricultural transformation under colonialism: the case of Taiwan." J. of Economic History 28 (Sept.): $311-40$.

Huang Jikun 黄季琨 (2011) “农民专业合作社经济组织发展的成就、挑战和对策” (The development of peasant specialty co-ops: accomplishments, challenges, and countermeasures). http://www.snzg.net/article/2011/1123/article_26361.html. 
Huang, Philip C. C. (1990) The Peasant Family and Rural Development in the Yangzi Delta, 1350-1988. Stanford, CA: Stanford Univ. Press.

Huang, Philip C. C. (2012) "Profit-making state firms and China's development experience: 'state capitalism' or 'socialist market economy?" Modern China 38, 6 (Nov.): 591-629.

Huang, Philip C. C. [ed.] (2013) "Development 'planning' in present-day China-system, process, and mechanisms: dialogues among Western and Chinese scholars, vi." Modern China 39, 6 (Nov.): 575-652.

Huang, Philip C. C. (2014) "Is family farms the way to develop Chinese agriculture?" Rural China 11, 2: 189-221.

Huang, Philip C. C. (2016) “China's hidden agricultural revolution, 1980-2010: in historical and comparative perspective.” Modern China 42, 4 (July): 339-76.

Huang, Philip C. C. and Yuan Gao (2013) "The dynamics of capitalization in Chinese agriculture: private firms, the state, or peasant households?" Rural China 10, 1:36-65.

Huang, Philip C. C., Yuan Gao, and Yusheng Peng (2012) "Capitalization without proletarianization in China's agricultural development." Modern China 38, 2 (Mar.): 139-73.

Huang Zongzhi 黄宗智 [Philip C. C. Huang] (2006)“制度化了的“半工半耕”过密型农业” (The institutionalized "part worker part cultivator" system of involutionary agriculture). 读书 (Dushu) no. 2: 30-37; no. 3: 72-80.

Huang Zongzhi 黄宗智 [Philip C. C. Huang] (2010) 中国的隐性农业革命 (China's hidden agricultural revolution). Beijing: Falü chubanshe.

Huang Zongzhi 黄宗智 [Philip C. C. Huang] (2012)“小农户与大商业资本的不平等交易： 中国现代农业的特色” (The unequal exchanges between small peasants and big commercial capital: the distinctive characteristic of modern Chinese agriculture). 开放时代 (Open Times) 3: 89-99.

Huang Zongzhi 黄宗智 [Philip C. C. Huang] (2014a) 超越左右：从实践历史探寻中国农村 发展出路 (Beyond the left and the right: searching for a path of development for rural China from the history of practice). Vol. 3 of 明清以来的乡村社会经济变迁：历史、理论、与现 实 (Rural social-economic change from the Ming and Qing: history, theory, and the present). Beijing: Falü chubanshe.

Huang Zongzhi 黄宗智 [Philip C. C. Huang] (2014b)““家庭农场”是中国农业的发展出路 吗? ” (Is "family farms" the way to develop Chinese agriculture?). 开放时代 (Open Times) 2: $176-94$.

Huang Zongzhi 黄宗智 [Philip C. C. Huang] (2015) “农业合作化路径选择的两大盲点：东 亚农业合作化历史经验的启示” (The two big blind spots in searching for a path for agricultural cooperatives: lessons from the East Asian experience). 开放时代 (Open Times) 5 (Sept.): $18-35$.

Huang Zongzhi 黄宗智 [Philip C. C. Huang] and Gao Yuan 高原 (2012) “小农户与大商业资本 的不平等交易：中国现代农业的特色” (Unequal transactions between small-peasant households and big commercial capital: the distinctive characteristic of China's modern agriculture). 开放时代 (Open Times) 3: 88-99.

Huang Zongzhi 黄宗智 [Philip C. C. Huang] and Gao Yuan 高原 (2013) “中国农业资本化的动 力：公司、国家、还是农户? ” (The dynamics of the capitalization in Chinese agriculture: private firms, the state, or peasant households?). 中国乡村研究 (Rural China: An International Journal of History and Social Science), vol. 10:28-50. 福州: 福建教育出版社.

Huang Zongzhi 黄宗智 [Philip C. C. Huang] and Gao Yuan 高原 (2014) “大豆生产和进口的经 济逻辑” (The economic logic of soybeans production and importation). 开放时代 (Open Times) 1: 176-88.

Huang Zongzhi 黄宗智 [Philip C. C. Huang], Gong Weigang 龚为纲, and Gao Yuan (2014)“ “项目 制” 的运作机制和效果是 “合理化' 吗? ” (Governance by project grants: do its operative mechanisms and results amount to "rationalization"?). 开放时代 (Open Times) 5: 143-59.

Huang Zongzhi 黄宗智 [Philip C. C. Huang] and Peng Yusheng 彭玉生 (2007) “三大历史性变迁 的交汇与中国小规模农业的前景” (The confluence of three historic tendencies and the prospects for China's small farming in the future). 中国社会科学 (Social Sciences in China) 4: $74-88$. 
Kang, Kenneth and Vijaya Ramachandran (1999) "Economic transformation in Korea: rapid growth without an agricultural revolution?" Economic Development and Cultural Change 47, 4 (July): 783-801.

Krugman, Paul (2008) "The increasing returns revolution in trade and geography." Nobel Prize lecture.

Kurimoto, Akira (2004) "Agricultural cooperatives in Japan: an institutional approach." J. of Rural Cooperation 32, 2: 111-18.

Liangshi shouchu gongying anquan baozhang gongcheng jianshe guihua 粮食收储供应安全保 障工程建设规划 (2015-2020年) [Planning for ensuring the security of the collecting and storing and supplying of grain, 2015-2020)] (2015). http://www.sdpc.gov.cn/zcfb/zcfbghwb/201506/ t20150624_696914.html.

Li Kai 李凯, Zhao Tao 赵涛, Wang Liyang 王立阳, Du Suxia 杜素霞, and Li Xiaomei 李晓梅 (2014) “引科技提升蔬菜质量 抓市场拓宽销售渠道——永年县搞好蔬菜上档升 级解决卖菜难问题调研报告” (Bringing in science and technology to raise the quality of vegetable production; grasping the market to expand the avenues for selling the products-an investigative report on Yongnian county's efforts to raise the level of vegetable production to solve the problem of difficulties in selling vegetables). 现代农村科技 15: 4-6.

Lin Huihuang 林辉煌 (2012) “江汉平原的农民流动与阶层分化：1981-2010：以湖北曙 光村委考察对象” (Peasant mobility and stratification on the Jiang-Han plain, 1981-2010: with Shuguang village in Hubei as an illustration). 开放时代 (Open Times) 3: 47-70.

Liu Laoshi 刘老石 (2010) “合作社实践与本土评价标准” (The practice of co-ops and the indigenous standard of evaluation). 开放时代 (Open Times) 12. http://www.opentimes.cn/bencandy. php?fid=170\&aid $=892$.

Moore, Richard H. (1990) Japanese Agriculture: Patterns of Rural Development. Boulder, co: Westview.

Perkins, Dwight H. and Shahid Yusuf (1984) Rural Development in China. Baltimore: Johns Hopkins Univ. Press (for the World Bank).

“Rang nongmin hezuoshe yunxing genghao shili gengqiang” 让农民合作社运行更好实力更强 [Make peasant co-ops even better and stronger] (2014) 农民日报, Sept. 27. http://szb.farmer.com .cn/nmrb/html/2014-09/27/nw.D110000nmrb_20140927_3-01.htm.

Wang Defu王德福 (2016) “市场化抑或政策性: 农地经营权抵押的实践逻辑与反思” (A matter of marketization or of policy: the logic of practice and rethinking of the use rights of land as security for loans). http://www.snzg.cn/article/2016/0314/article_41539.html.

Wang Haijuan 王海娟 (2015) “资本下乡的政治逻辑与治理逻辑” (The political and governance logic of “capital going down to the countryside"). 西南大学学报 4. http://www.snzg.net/ article/2015/0818/article_41271.html.

Wang Xiaolu 王小鲁, Jiang Sidong 姜斯栋, and Cui Heming 崔鹤鸣 (2015) “综合性农民合 作组织是实现中国农村现代化的重要组织形式一山西省永济市蒲韩农协调研 报告” (The integrated peasant co-op is an important form of organization for realizing rural modernization in China: an investigative report on the Pu-Han peasant co-op of Yongii city in Shanxi province). In 杨团, 孙炳耀等著: 《综合农协中国 “三农” 改革突破口2015 卷》 (Farmers' integrated cooperatives: a breakthrough in China's rural reform), 第285至306页. 北 京: 社会科学文献出版社.

Yang Hua 杨华 (2012) ““中农”阶层: 当前农村社会的中间阶层” (The “middle peasant” class: the intermediate group of rural society today). 开放时代 (Open Times) 3: 71-87.

Yang Tuan 杨团 (2013) “综合农协改革逐渐被官学两界关注.”财经 (Caijing), Sept. 2. http:// finance.sina.com.cn/china/20130902/180216639711.shtml.

Yang Tuan 杨团, Sun Bingyao 孙炳耀, Zheng Yisheng 郑易生, Tong Zhihui 全志辉, Liu Jianjin 刘 建进, and Shi Yuancheng 石远成 (2013) “探索综合性农民合作组织, 促进 “三农” 改 革新突破” (Searching for an integrated approach to peasants cooperative organization, and promoting new breakthroughs in reform of the "triple problem" [of peasants, agriculture, and villages]). In Yang Tuan, Sun Bingyao, et al., 综合农协中国 “三农” 改革突破口 (Farmers' integrated cooperatives: a breakthrough in China's rural reform), 第 8 至 42 页. 北 京: 会科学文献出版社. 
Yuan Zhonghua 袁中华 (n.d.) “农业结构转型与适度规模的生成一一基于对鲁西 S县小 肉鸡产业的历时性观察与思考” (The structural transformation of agriculture and the formation of appropriate scale economies: based on diachronic observations and reflections on the "small meat chickens" industry of western Shandong's "S" county). Unpublished paper. Zeng Yinchu 曾寅初 (2007) “农产品批发市场升级改造的难点与对策一基于浙江、 山东两省的调查分析” (The difficulties in raising the standard of the wholesale markets for agricultural products and possible solutions_-based on research from Zhejiang and Shandong provinces). 中国市场, Z4: 63-66.

Zhang Jianlei 张建雷 (n.d.) 发展型小农家庭的兴起: 市场、制度与农民家庭的互 构一一皖东溪水镇的小农家庭与乡村变迁（1980-2015） [Developmental mode peasant family farms: mutually formative markets, institutions and peasant families-the smallpeasant families and social change in Xishui township in eastern Anhui]. Ph.D. diss. 华东理工大 学. (East China University of Science and Technology).

Zhang Jianlei, Jinqing Cao, and Yunyun Yang (2016) "The rise of the middle peasant economy: noncapitalistic agricultural development and its mechanism: the case of Wu Village, Anhui." Rural China 13, 1: 47-76.

Zhang, Qian Forrest, Carlos Oya, and Jingzong Ye (2015) "Bringing agriculture back in: the central place of agrarian change in rural China studies." J. of Agrarian Change 15, 3: 299-313.

Zhang Yongge 张永革 (2014) “永年县蔬菜生产现状与发展对策” (The current situation of vegetable production in Yongnian county and suggested policies for development). 农业科技 通讯 8: 37-38, 156 .

Zheng Lintao 郑林涛 (2013) “关于寿光县化龙镇胡罗卜产业发展的调研报告” (Investigative report on the development of the carrots industry in Hualong township, Shouguang county). 今日中国论坛 17: 174-75.

"Zhonggong zhongyang guowuyuan guanyu shenhua gongxiaohezuoshe zonghe gaige de jueding" 中共中央国务院关于深化供销合作社综合改革的决定 [Decisions of the Party Central's State Council on deepening integrated reform of the supply and marketing co-ops] (2015) Xinhua, April 2. http://news.xinhuanet.com/politics/2015-04/02/c_1114855360.htm (accessed Mar. 7, 2016).

Zhongguo nongcun tongji nianjian 中国农村统计年鉴 [Statistical yearbook of rural China] (2002, 2011) Beijing: Zhongguo tongji chubanshe.

Zhongguo tongji nianjian 中国统计年鉴 [Statistical yearbook of China] $(1983,1984,1987,2011$, 2015) Beijing: Zhongguo tongji chubanshe.

“Zhonghua renmin gongheguo nongmin zhuanye hezuoshe fa” 中华人民共和国农民专业合作 社法 [Peasant specialty co-ops law of the People's Republic of China] (2006). http://www.gov.cn/ flfg/2006-10/31/content_429392.htm.

"Zhongyang yihao wenjian" 中央一号文件 [Number one documents of the [Party] Central] (2004, 2005, 2006, 2007, 2008, 2009, 2010, 2011, 2012, 2013, 2014). http://www.moa.gov.cn/ztzl/ yhwj2015/wjhg_1/ (accessed April 8, 2016).

“Zhongyang yihao wenjian” 中央一号文件 [Number one documents of the [Party] Central] (2015). http://www.moa.gov.cn/ztzl/yhwj2015/zywj/201502/t20150202_4378754.htm (accessed April 8, 2016).

“Zhongyang yihao wenjian” 中央一号文件 [Number one documents of the [Party] Central] (2016). http://www.moa.gov.cn/ztzl/2016zyyhwj/2016zyyhwj/201601/t20160129_5002063.htm (accessed April 8, 2016). 